\title{
Synaptic Function of Rab11Fip5: Selective Requirement for Hippocampal Long-Term Depression
}

\author{
Taulant Bacaj, ${ }^{1 \star}$ Mohiuddin Ahmad, ${ }^{2,3 *}$ CSandra Jurado, ${ }^{2,4 \star}$ Robert C. Malenka, ${ }^{2}$ and Thomas C. Südhof ${ }^{1}$ \\ ${ }^{1}$ Department of Molecular and Cellular Physiology and Howard Hughes Medical Institute, Stanford University Medical School, Stanford, California 94305, \\ ${ }^{2}$ Nancy Pritzker Laboratory, Department of Psychiatry and Behavioral Sciences, Stanford University Medical School, Stanford, California 94305, \\ ${ }^{3}$ Department of Cell Biology, University of Oklahoma Health Sciences Center, Oklahoma City, Oklahoma 73104, and ${ }^{4}$ Department of Pharmacology, \\ University of Maryland School of Medicine, Baltimore, Maryland 21201
}

\begin{abstract}
Postsynaptic AMPA-type glutamate receptors (AMPARs) are among the major determinants of synaptic strength and can be trafficked into and out of synapses. Neuronal activity regulates AMPAR trafficking during synaptic plasticity to induce long-term changes in synaptic strength, including long-term potentiation (LTP) and long-term depression (LTD). Rab family GTPases regulate most membrane trafficking in eukaryotic cells; particularly, Rab11 and its effectors are implicated in mediating postsynaptic AMPAR insertion during LTP. To explore the synaptic function of Rab11Fip5, a neuronal Rab11 effector and a candidate autism-spectrum disorder gene, we performed shRNA-mediated knock-down and genetic knock-out (KO) studies. Surprisingly, we observed robust shRNA-induced synaptic phenotypes that were rescued by a Rab11Fip5 cDNA but that were nevertheless not observed in conditional K0 neurons. Both in cultured neurons and acute slices, K0 of Rab11Fip5 had no significant effect on basic parameters of synaptic transmission, indicating that Rab11Fip5 is not required for fundamental synaptic operations, such as neurotransmitter release or postsynaptic AMPAR insertion. K0 of Rab11Fip5 did, however, abolish hippocampal LTD as measured both in acute slices or using a chemical LTD protocol in cultured neurons but did not affect hippocampal LTP. The Rab11Fip5 K0 mice performed normally in several behavioral tasks, including fear conditioning, but showed enhanced contextual fear extinction. These are the first findings to suggest a requirement for Rab11Fip5, and presumably Rab11, during LTD.
\end{abstract}

Key words: autism; LTD; Rab11; Rab11Fip5

\section{Introduction}

Neurons, like all eukaryotic cells, require intracellular membrane trafficking to function properly. Particularly at synapses, presynaptic neurotransmitter release necessitates exquisite control of synaptic vesicle fusion followed by recycling (Südhof, 2012). In excitatory postsynaptic neurons, the presence and number of AMPA receptors (AMPARs), which detect glutamate, are also controlled by vesicle trafficking on a much slower time scale. Specifically, AMPARs are inserted or removed from the postsynaptic membrane in an activity-dependent manner, leading to long-lasting changes in synaptic strength, such as long-term potentiation (LTP) and long-term depression (LTD), respectively (Malenka and Bear, 2004; Huganir and Nicoll, 2013).

\footnotetext{
Received April 17, 2014; revised March 28, 2015; accepted March 31, 2015.

Author contributions: T.B., M.A., S.J., R.C.M., and T.C.S. designed research; T.B., M.A., and S.J. performed research; T.B., M.A., S.J., R.C.M., and T.C.S. analyzed data; T.B., M.A., S.J., R.C.M., and T.C.S. wrote the paper.

This work was supported by National Institute of Neurological Disorders and Stroke fellowships 1F32NS067896 and 1 K99NS087086 to T.B. and by National Institutes of Health Grants P50MH086403 and R01NS077906 to R.C.M. and T.C.S. We thank Ira Huryeva for technical support.

The authors declare no competing financial interests.

*T.B., M.A., and S.J. contributed equally to this work.

Correspondence should be addressed to either Dr. Taulant Bacaj or Thomas C. Südhof, Stanford University Medical School, 265 Campus Drive, Stanford, CA 94305-5453. E-mail: tbacaj@gmail.com or tcs1@stanford.edu.

DOI:10.1523/JNEUROSCI.1581-14.2015

Copyright $\odot 2015$ the authors $\quad 0270-6474 / 15 / 357460-15 \$ 15.00 / 0$
}

Small Rab-type GTPases are key regulators of intracellular membrane sorting in all cells, including neurons (Stenmark, 2009). In the presynaptic terminal, synaptic vesicle dynamics are controlled primarily by Rab3 (Schlüter et al., 2004). Postsynaptically, AMPARs undergo intricate trafficking patterns and are dynamically allocated to different compartments based on ongoing synaptic activity. After internalization, endocytosed AMPARs may be directly shuttled back to the plasma membrane via Rab4 or sent to recycling endosomes via Rab11 (Park et al., 2004; Brown et al., 2007). The divergence between the LTP and LTD trafficking pathways may occur within early endosomes and involve distinct Rabs. Specifically, it has been suggested that AMPARs in early recycling endosomes recycle back to the surface via a Rab11 and Rab8 pathway (Park et al., 2004; Brown et al., 2007) or are delivered to late endosomes and later lysosomes for degradation via Rab7 (Press et al., 1998; Fernández-Monreal et al., 2012).

In light of coordinated "Rab cascades" (Pfeffer, 2013), Rab11 is critically situated to direct receptor targeting to the membrane versus the lysosome. Rab11 is known to interact with several proteins, including five Rab11Fip's (Prekeris et al., 2000; Hales et al., 2001), which probably enable its versatility. These Rab11Fip molecules are characterized by a C-terminal Rab11 binding domain and can be grouped into two classes: Class I (Rab11Fip1/2/5), which possess N-terminal C2 domains; and Class II (Rab11Fip3/4), which contain EF-hand domains (Horgan and McCaffrey, 2009). 
The known Rab11Fip roles can be broadly classified intro three groups subserving different functions: recycling of cargo to the plasma membrane (Prekeris et al., 2000; Lindsay and McCaffrey, 2002; Welsh et al., 2007), delivery of membrane to the cleavage furrow during cell division (Fielding et al., 2005; Wilson et al., 2005), and coupling Rab11 to molecular motor proteins (Hales et al., 2002; Schonteich et al., 2008; Simon and Prekeris, 2008).

Rab11Fip5, in particular, is required for the translocation of GLUT4 in adipocytes (Welsh et al., 2007), insulin in pancreatic $\beta$-cells (Sugawara et al., 2009), and V-ATPase in duct cells (Oehlke et al., 2011) from intracellular pools to the cell surface. Furthermore, human genetic studies have identified Rab11Fip5 as an autism candidate gene (Roohi et al., 2008; Matsunami et al., 2014). Here, we address the neuronal functions of Rab11Fip5 and find no evidence for a requisite role of Rab11Fip5 in basal transmission or hippocampal LTP. However, Rab11Fip5 KO mice have severely impaired LTD, likely because internalized AMPARs are not appropriately targeted to the intracellular organelles that prevent recycling back to the plasma membrane.

\section{Materials and Methods}

Generation of lentiviral RNAi vectors. All lentiviral transfection and infection experiments for shRNA expression were performed as described previously (Ho et al., 2006; Pang et al., 2010). The Rab11Fip5 KD (KD51 5'-GTATGATCTCGAATCTGCCTC-3') was cloned in a thirdgeneration lentiviral backbone, L309 (Pang et al., 2010), under the control of the $\mathrm{H} 1$ promoter to yield TB51. The lentiviral Cre and $\Delta$ Cre have been described previously (Kaeser et al., 2011). For the Rab11Fip5 rescue constructs, a mouse cDNA encoding for the 645 amino acid isoform was used; the first $420 \mathrm{bp}$ of this cDNA was synthesized and the DNA was recoded to reduce the GC-content. The Rab11Fip5 cDNA was cloned in L309 or TB51 with BamHI/EcoRI to produce the overexpression (TB477) or KD+rescue (TB441) lentiviral vectors, which were used for rescues. The same cDNA was used to generate the Rab11Fip5+Cre vector (TB611). Viruses were generated by transfection of the lentiviral vector alongside the three packaging vectors into human embryonic kidney cells. Viral preps were tittered to ensure consistent infection rates. In all cases, the viral titer used results in infection rates $>99 \%$. Infection was confirmed visually at the time of recordings as all lentiviral vectors express green fluorescent protein. Further, addition of two different viruses results in "superinfection" without measurably changing the infectivity of each virus.

Hippocampal neuronal culture. Cultures were produced from WT and Rab11Fip5 cKO mice as described previously (Maximov et al., 2007). Briefly, hippocampi were dissected from P0 pups, dissociated by papain digestion, and plated on Matrigel-coated glass coverslips. Neurons were cultured for 14-16 DIV in MEM (Invitrogen) supplemented with B27 (Invitrogen ), glucose, transferrin, FBS, and Ara-C (Sigma).

Generation of Rab11Fip5 KO mice. The Rab11Fip5 mice were customgenerated by Taconic based on the strategy shown in Figure 3. The initial mouse background was C57BL/6NTac, but mice were backcrossed to C57BL/6J for at least three generations. The initial neomycin-containing mouse line (F5N) was genotyped by PCR with oligonucleotide primers TB11883 (5'-GCTCACCAAGCCACAGCAGCTG-3') and TB11884 (5' GGCCTCATCACTGTATGTCCTCTTGTG-3') yielding products of two different sizes, wild-type ( $200 \mathrm{bp})$ and mutant $(288 \mathrm{bp})$. The neomycin cassette was removed by crossing to FLPe transgenic mice (The Jackson Laboratory, RRID:IMSR_JAX:005703), and the resulting F5F mice were genotyped with the primers TB11885 ( $5^{\prime}$-TGCTTGCCATGATCTGTCCT-3') and TB11886 (5'-GGAGCAAGTGGACTTGTTGG-3'), yielding bands of $330 \mathrm{bp}$ for the wild-type and $487 \mathrm{bp}$ for the mutant allele. Constitutive $\mathrm{KO}$ mice (F5C) generated by breeding to Cre mice (The Jackson Laboratory, RRID:IMSR_JAX:006054), were genotyped with primers TB11885 and TB11887 (5'-GAGGTTCCTCATTGTACACATGG- $3^{\prime}$ ) and yield a 442 bp band in the KO allele. The F5N mouse line has been submitted to The Jackson Laboratory for distribution.

Protein and $m R N A$ quantification. For protein measurements, wholebrain homogenates from 3 littermate pairs were isolated. Protein con- tents were adjusted by use of a BCA protein assay kit (Pierce Biotechnology), and equal levels of protein were loaded by SDS-PAGE gels for immunoblotting analysis. After the primary antibody, ${ }^{125} \mathrm{I}-$ labeled secondary antibodies were used and detected with a phosphoimager. mRNA measurements were performed as described previously (Pang et al., 2011). RNA was isolated from neuronal cultures at DIV 14. Two different qPCR probes were used for measurements; probe 1 recognizes the exon 1-2 junction, which is recoded, hence not recognized, in the rescuing cDNA, and probe 2 recognizes the junction of exons $4-5$ and does detect the rescuing cDNA.

Electrophysiological recordings in cultured neurons. Recordings were performed essentially as described previously (Bacaj et al., 2013). Briefly, the resistance of pipettes filled with intracellular solution varied between 2 and $3 \mathrm{MOhm}$ and the series resistance was 7-10 MOhm. Synaptic currents were monitored with a Multiclamp 700B amplifier (Molecular Devices). The frequency, duration, and magnitude of the extracellular stimulus were controlled with a Model 2100 Isolated Pulse Stimulator (A-M Systems) synchronized with the Clampex 10 data acquisition software (Molecular Devices). Evoked synaptic responses were triggered by a bipolar electrode. The whole-cell pipette solution contained (in $\mathrm{mM}$ ) the following: $135 \mathrm{CsCl}, 10 \mathrm{HEPES}, 1$ EGTA, $1 \mathrm{Na}-\mathrm{GTP}, 4 \mathrm{Mg}$-ATP, and 10 QX-314 (pH 7.4, adjusted with CsOH). The bath solution contained (in mM) the following: $140 \mathrm{NaCl}, 5 \mathrm{KCl}, 2 \mathrm{CaCl}_{2}, 2 \mathrm{MgCl}_{2}, 10$ HEPES, 10 glucose ( $\mathrm{pH} 7.4$, adjusted with $\mathrm{NaOH})$. AMPAR-mediated EPSCs were pharmacologically isolated with picrotoxin $(50 \mu \mathrm{M})$ and AP-5 $(50 \mu \mathrm{M})$ and recorded at a $-70 \mathrm{mV}$ holding potential, NMDAR-mediated EPSCs with picrotoxin $(50 \mu \mathrm{M})$ and CNQX $(20 \mu \mathrm{M})$ and recorded at a $40 \mathrm{mV}$ holding potential, and IPSCs with CNQX $(20 \mu \mathrm{M})$ and AP-5 $(50 \mu \mathrm{M})$ and recorded at a $-70 \mathrm{mV}$ holding potential; all drugs were applied to the bath solution. IPSCs were recorded with a high internal $\mathrm{Cl}^{-}$solution, resulting in large inward currents. mIPSCs and mEPSCs were monitored in the presence of TTX $(1 \mu \mathrm{M})$ in addition to the compounds listed above. Miniature events were analyzed in Clampfit 9.02 (Molecular Devices) using the template matching search and a minimal threshold of $5 \mathrm{pA}$, and each event was visually inspected for inclusion or rejection. For all electrophysiological experiments, the experimenter was blind to the condition/genotype of the cultures analyzed.

Slice electrophysiology. Three- to 4 -week-old mice were anesthetized with isoflurane, and the brains rapidly removed and placed in ice-cold, high sucrose cutting solution containing (in $\mathrm{mm}$ ) the following: $228 \mathrm{su}-$ crose, $26 \mathrm{NaHCO}_{3}, 11$ glucose, $2.5 \mathrm{KCl}, 1 \mathrm{NaH}_{2} \mathrm{PO}_{4}, 7 \mathrm{MgSO}_{4}$, and 0.5 $\mathrm{CaCl}_{2}$. The $250 \mu \mathrm{m}$ slices were cut on a Leica vibratome in the high sucrose cutting solution and immediately transferred to an incubation chamber having ACSF containing (in $\mathrm{mM}$ ) the following: $119 \mathrm{NaCl}, 26$ $\mathrm{NaHCO}_{3}, 11$ glucose, $2.5 \mathrm{KCl}, 1 \mathrm{NaH}_{2} \mathrm{PO}_{4}, 1.3 \mathrm{MgSO}_{4}$, and $2.5 \mathrm{CaCl}_{2}$. The slices were allowed to recover at $32^{\circ} \mathrm{C}$ for $30 \mathrm{~min}$ and then at room temperature for $1 \mathrm{~h}$. During recordings, the slices were placed in a recording chamber constantly perfused with heated ACSF $\left(28^{\circ} \mathrm{C}-30^{\circ} \mathrm{C}\right)$ and gassed continuously with $95 \% \mathrm{O}_{2}$ and $5 \% \mathrm{CO}_{2}$. All recordings were made with the GABAA receptor antagonist picrotoxin $(50 \mu \mathrm{M})$ added to the ACSF. Data were collected with a MultiClamp 700B amplifier (Molecular Devices) and digitized at $10 \mathrm{kHz}$ using the A/D converter ITC-18 (Instrutech). Data were acquired and analyzed using a custom program written with Igor Pro software (Wavemetrics).

For extracellular field recordings, the recording glass pipette was filled with ACSF and placed in the stratum radiatum of the CA1 region of the hippocampus. A double-barreled glass pipette filled with ACSF was used as a bipolar stimulation electrode and was placed in stratum radiatum. The Schaffer collateral axons were stimulated at $0.1 \mathrm{~Hz}$ to obtain baseline fEPSPs for at least $20 \mathrm{~min}$. LTP was induced by 2 trains of high-frequency stimulation $(100 \mathrm{~Hz}, 1 \mathrm{~s})$ separated by $20 \mathrm{~s}$. LTD was induced by a train of low-frequency stimulation $(2 \mathrm{~Hz}, 7.5 \mathrm{~min})$. To generate summary graphs, individual experiments were normalized to the baseline, and six consecutive responses were averaged to generate $1 \mathrm{~min}$ bins. These were then averaged together to generate the final summary graphs. The magnitude of LTP and LTD was calculated based on the fEPSP values 50-55 min after the end of the induction protocols. For input-output measurements, 5-10 traces were averaged for each stimulation intensity, and the amplitude of the presynaptic fiber-volley was measured relative to the slope 
of the fEPSP. The stimulation rate was $0.1 \mathrm{~Hz}$. The average linear fit slope was calculated as the slope of the linear input-output relationship for each slice.

For whole-cell patch clamp, recording pipettes (3-5 $\mathrm{M} \Omega$ ) were filled with a solution containing (in $\mathrm{mM}$ ) the following: $117.5 \mathrm{CsMeSO}_{4}, 10$ HEPES, 10 TEACl, 15 CsCl, $8 \mathrm{NaCl}$, $0.3 \mathrm{NaGTP}, 4 \mathrm{MgATP}, 0.2$ EGTA, 5 QX-314 (pH 7.20-7.30; osmolarity 295-300). The CA1 pyramidal neurons were held at $-70 \mathrm{mV}$ to record AMPAR EPSCs while stimulating afferent inputs at $0.1 \mathrm{~Hz}$. LTP was induced by 2 trains of high-frequency stimulation $(100 \mathrm{~Hz}, 1 \mathrm{~s})$ separated by $20 \mathrm{~s}$ and cells were depolarized to $0 \mathrm{mV}$. This induction protocol was always applied within $10 \mathrm{~min}$ of achieving whole-cell configuration, to avoid "wash-out" of LTP. To induce LTD, cells were held at $-40 \mathrm{mV}$, and 2 trains of low-frequency stimulation $(5 \mathrm{~Hz}, 3 \mathrm{~min})$ separated by $4 \mathrm{~min}$ were applied. To generate summary graphs, individual experiments were normalized to the baseline, and six consecutive responses were averaged to generate $1 \mathrm{~min}$ bins. These were then averaged together to generate the final summary graphs. The magnitude of LTP and LTD was calculated based on the EPSC values 35-40 min and 30-35 min after the end of the induction protocols, respectively. The AMPAR/NMDAR ratio was calculated as the peak averaged AMPAR EPSC ( $30-50$ consecutive events) at $-60 \mathrm{mV}$ divided by the averaged NMDAR EPSCs ( $20-40$ consecutive events) measured at 50 $\mathrm{ms}$ after the onset of the dual component EPSCs at $40 \mathrm{mV}$. AMPAR mEPSCs were recorded in the presence of TTX $(0.5 \mu \mathrm{M})$ holding the cells at $-60 \mathrm{mV}$. All data are presented as mean $\pm \mathrm{SEM}$. Statistical significance was calculated between interleaved control cells and test cells using $t$ test.

Immunocytochemistry and AMPAR endocytosis. The surface expression of AMPARs in Rab11Fip5 cKO neurons was assayed by labeling surface AMPARs in live neurons for $15 \mathrm{~min}$ at $37^{\circ} \mathrm{C}$ with a GluA1 rabbit polyclonal antibody PC246 (Calbiochem, catalog \#PC246, RRID: AB_564636) diluted 1:4 in PBS supplemented with $2 \mathrm{mM} \mathrm{Ca}^{2+}$ and $\mathrm{Mg}^{2+}$. After washing, cells were fixed in $4 \% \mathrm{PFA}+4 \%$ sucrose on ice for 15 min without permeabilization, blocked in $2 \%$ goat serum in PBS for $1 \mathrm{~h}$, incubated in secondary antibody for $1 \mathrm{~h}$. To label PSD95, the cultures were then permeabilized in $-20^{\circ} \mathrm{C}$ methanol for $1 \mathrm{~min}$, blocked for $1 \mathrm{~h}$, incubated with a PSD95 primary antibody (Thermo Pierce, catalog \#MA1-046, RRID:AB_2092361), washed, incubated with a secondary antibody, mounted, and imaged. The AMPAR endocytosis assay was performed as described previously (Bhattacharyya et al., 2009). Surface receptors were first labeled with the GluAlantibody for 15 min in MEM. After washing, cells were preincubated with $1 \mu \mathrm{M}$ TTX $+100 \mu \mathrm{M}$ LY341495 + $20 \mu \mathrm{M}$ DNQX for 5 min followed by the addition of $100 \mu \mathrm{M}$ NMDA for $3 \mathrm{~min}$. Coverslips were washed and returned to the original media at $37^{\circ} \mathrm{C}$ for $15 \mathrm{~min}$. Cells were fixed without permeabilization, and surface receptors were stained with a saturating concentration of AlexaFluor-546 secondary antibody (Invitrogen). Cells were then permeabilized with methanol, and internalized GluA1 receptors were stained with an AlexaFluor-633 secondary antibody.

Image acquisition and analysis. Coverslips were imaged on a Leica DMIRE2 laser scanning confocal microscope using a $63 \times$ objective. Images for all conditions in a particular experiment were obtained using identical acquisition parameters (gain, offset, laser power, pinhole size, scan speed, etc.) and were analyzed using MATLAB using identical parameters (e.g., threshold value). The algorithm first identified dendritic branches in collapsed $Z$-stack images and then measured total fluorescence levels above background for the surface and internal GluA1 signal. The ratio of internalized receptors was calculated as the intracellular fluorescence divided by total fluorescence (intracellular plus surface). These values were then normalized to those of the untreated control cells from the same experiment. Six coverslips from three different cultures were analyzed, and differences were assessed with Student's $t$ test.

Behavioral analysis. Eight- to 12-week-old, littermate, male mice were used in all behaviors. Mice were handled daily for $5 \mathrm{~d}$ before training or testing. All experiments were conducted following protocols approved by Administrative Panel on Laboratory Animal Care at Stanford University.

Fear conditioning. Mice were trained in a fear conditioning chamber (H10-11M-TC, Coulbourn Instruments) located in a sound-attenuating cubicle (Coulbourn Instruments). The conditioning chamber was cleaned with $10 \%$ ethanol to provide a background odor and had a background noise of $\sim 55 \mathrm{~dB}$. After a 2 min habituation period, three tone- foot shock pairings separated by $1 \mathrm{~min}$ intervals were delivered. The tone $(85 \mathrm{~dB}, 2 \mathrm{kHz})$ lasted for $30 \mathrm{~s}$, and the foot shocks $(0.75 \mathrm{~mA})$ lasted for $2 \mathrm{~s}$ with foot shocks coterminating with the tone. The mice remained in the training chamber for 30 more seconds before being returned to home cages. In the context test, mice were placed back into the original conditioning chamber for $5 \mathrm{~min}$. The altered context and tone tests were conducted in a new conditioning chamber with altered floor, wall decorations, and the background odor was vanilla instead of ethanol. Mice were placed in the altered chamber for $5 \mathrm{~min}$ to measure the freeze level in the altered context; and after this 5 min period, a tone $(85 \mathrm{~dB}, 2$ $\mathrm{kHz}$ ) was delivered for $1 \mathrm{~min}$ to measure the freeze to the tone. For extinction trials, the same protocol as above was used. Context reexposure was performed over 4 consecutive days; the 10 tone extinction trials were conducted over 2 weeks, but the single intervening weekend was skipped. The mice were recorded with Freezeframe software and analyzed with Freezeview software (Coulbourn Instruments). Motionless bouts lasting $>1 \mathrm{~s}$ were considered freezing. For the extinction trials, two-way repeated-measures ANOVA was used with Bonferroni correction to test for significance.

Social preference test. The apparatus was a transparent Plexiglas, rectangular, three-chambered box $(60 \mathrm{~cm} \times 30 \mathrm{~cm} \times 30 \mathrm{~cm}$ high $)$ with the chambers connected by doors. The test mouse was placed in the middle chamber and allowed to explore for $5 \mathrm{~min}$. The doorways into the two side chambers were obstructed by an opaque divider during the habituation phase. In one chamber, an unfamiliar C57BL/6J male that had no prior contact with the subject mice was present. The stranger mouse was enclosed in a small, round wire cage. In the opposite chambers, two small black ovals approximately the size of a mouse were present inside an identical wire cage. Both doors to the side chambers were opened, and the subject was allowed to explore the entire social test box for $10 \mathrm{~min}$. The time spent in each chamber and the number of entries into each chamber were recorded and analyzed with Viewer III (Biobserv). Analysis was performed for the first $5 \mathrm{~min}$, the last $5 \mathrm{~min}$, or the whole $10 \mathrm{~min}$ session, and no differences were found in the three time frames.

$Y$ maze spontaneous alternation. Testing occurred in a Y-shaped maze (model 60180, Stoelting). The mouse was placed in the bottom chamber. The session was recorded, and the entry of the mouse in each arm was tracked with Viewer III. An entry was defined as all four limbs entering an arm. The number of arm entries and the number of correct triads (three consecutive visits to all three different arms) were determined and used to calculate the percentage of correct alternations.

Open-field test. Locomotor activity in the open-field test was measured using the ENV-510 test environment and Activity Monitor software (Med Associates). The activity box $(27 \times 27 \times 20 \mathrm{~cm})$ was housed inside a sound-attenuating chamber. Animals were placed in the center of the testing arena and allowed to freely move for $60 \mathrm{~min}$ while being tracked by an automated tracking system. Distance traveled, velocity, jump count, vertical count, time immobile, and time spent in the center area were determined.

Statistics. Most experiments were performed by experimenters unaware of the genetic condition of the samples. All data are shown as mean \pm SEM. Unless otherwise indicated, statistical analyses were performed by Student's $t$ test or one-way ANOVA for comparisons among three or more conditions.

\section{Results}

\section{Electrophysiological characterization of Rab11Fip5 shRNA} knockdown

To test whether Rab11Fip5 (also referred to as Rip11, Gaf-1/ Gaf1b, and pp75) is required for proper synaptic function, we sought to develop lentiviral shRNA constructs that could efficiently knock down (KD) the mRNA levels of Rab11Fip5. Of five shRNA sequences tested, only one reduced Rab11Fip5 mRNA expression to $<20 \%$ of the endogenous levels in cultured hippocampal neurons (Fig. 1B). To examine whether loss of Rab11Fip5 alters synaptic function, we measured spontaneous miniature IPSCs (mIPSCs) in cultured hippocampal neurons (Maximov et al., 2007) that were infected with control or shRNA- 
A
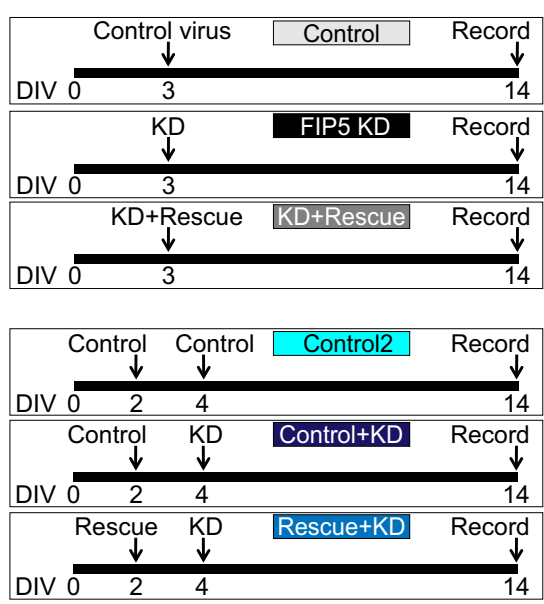

C

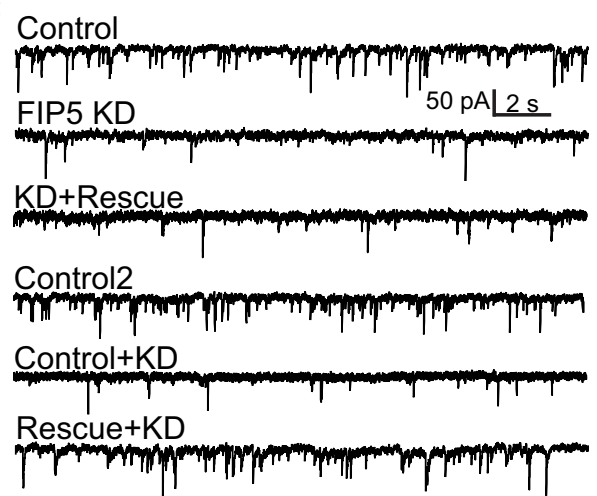

D

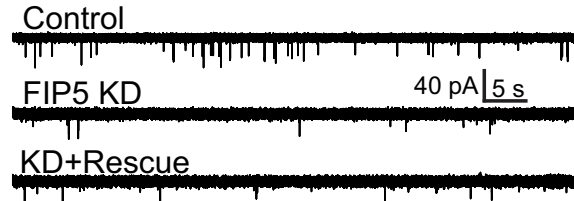

Control2

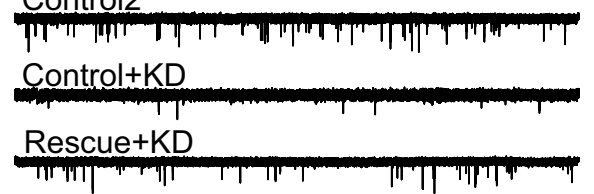

B

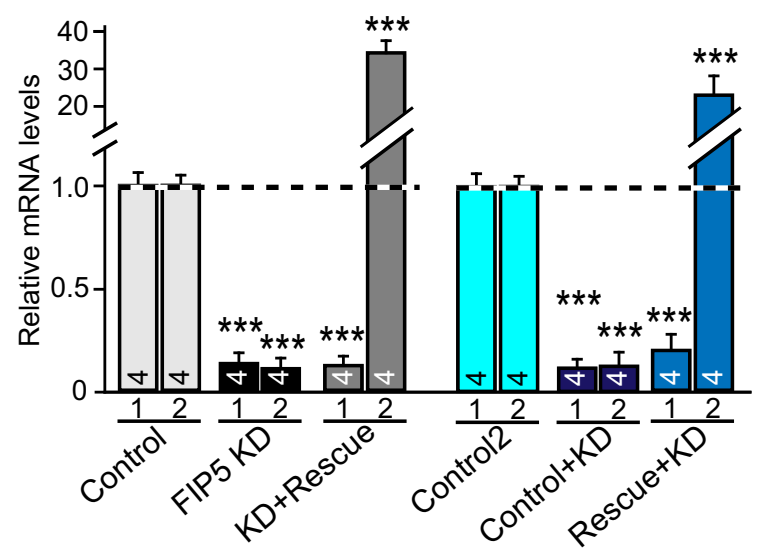

mIPSCs

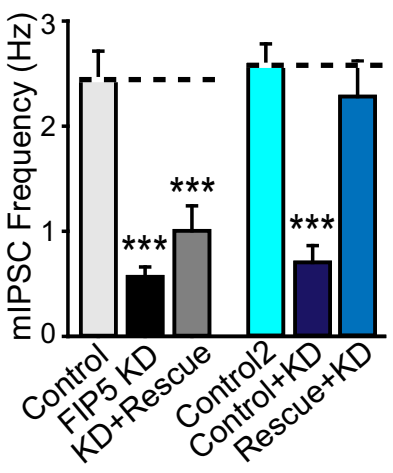

mEPSCs
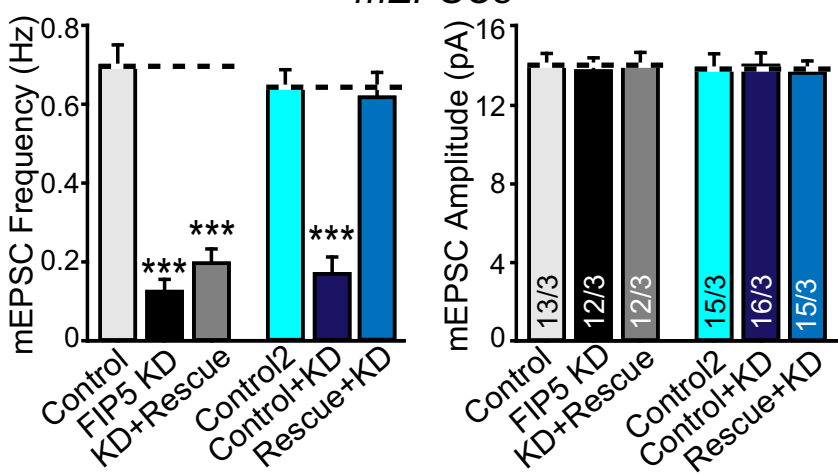

Figure 1. Characterization of Rab11Fip5 shRNA knockdown. A, Diagram of the treatment conditions (see also Fig. 2). The "KD+Rescue" condition is encoded in a single lentivirus. For the last three conditions, two virus infections were performed at days 2 and 4. $\boldsymbol{B}$, mRNA measurements for Rab11Fip5. Of the two probes, probe 1 does not recognize the rescuing cDNA. This allows measurements of the endogenous mRNA levels as well as expression of the rescuing construct. Rab11Fip5 mRNA levels were assayed by qRT-PCR and are normalized to those of GAPDH. $C$, Spontaneous mIPSCs recorded in cultured hippocampal neurons. Sample traces (left), event frequency (middle), and average amplitude (right) are shown. D, Spontaneous mEPSCs after Rab11Fip5 shRNA KD. The number of cells/cultures used is indicated in each graph. Graphs represent mean \pm SEM. ${ }^{* * *} p<0.001$ (one-way ANOVA).

bearing lentiviruses (for treatment conditions, see Fig. 1A). mIPSCs showed normal amplitudes but severely reduced frequency in $\mathrm{KD}$ cultures (Fig. $1 C$; $p<0.001$ ), suggesting a presynaptic alteration. The same reduction in frequency was observed for spontaneous excitatory events (mEPSCs) after Rab11Fip5 KD (Fig. $1 D ; p<0.001$ ). To examine evoked transmission, IPSCs were elicited by field stimulation using an external electrode (Maximov et al., 2007). Rab11Fip5 KD decreased evoked IPSC amplitudes and charge transfer by approximately threefold compared with control infected cells (Fig. $2 A ; p<0.001$ ). In addition, the $\mathrm{KD}$ construct also reduced charge transfer during a $1 \mathrm{~s} 10 \mathrm{~Hz}$ stimulus train as well as the synaptic depression normally ob- served during high-frequency trains (Fig. 2B). Such large reduction in eIPSC amplitude could result from a decrease in the pool of synaptic vesicles that are able to support synaptic transmission; therefore we determined the readily releasable pool of Rab11Fip5 KD neurons. The readily releasable pool, an indication of docked vesicles that can be measured by application of hypertonic sucrose (Rosenmund and Stevens, 1996), was reduced by more than half in KD neurons (Fig. 2C; $p<0.001$ ).

To verify that the observed shRNA KD phenotypes specifically arise from the absence of the targeted gene, we performed rescue experiments by expressing alongside the shRNA an shRNA-resistant cDNA of Rab11Fip5. Inclusion of recoded Rab11Fip5 cDNA in the KD 
A

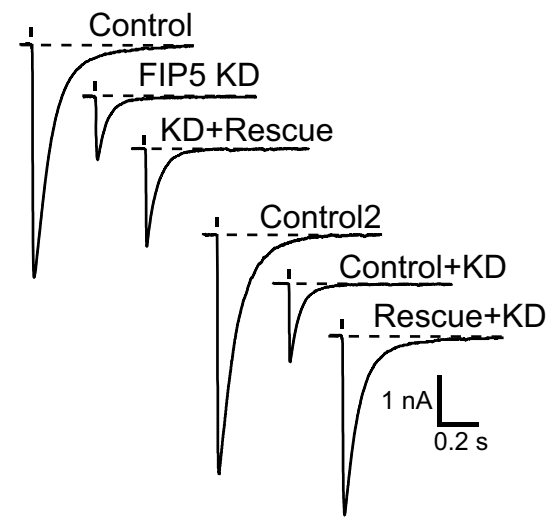

Isolated evoked IPSCs

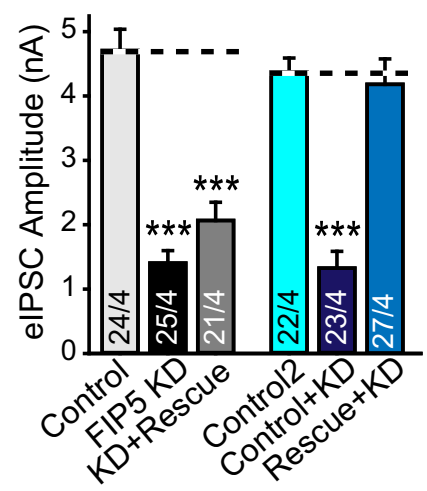

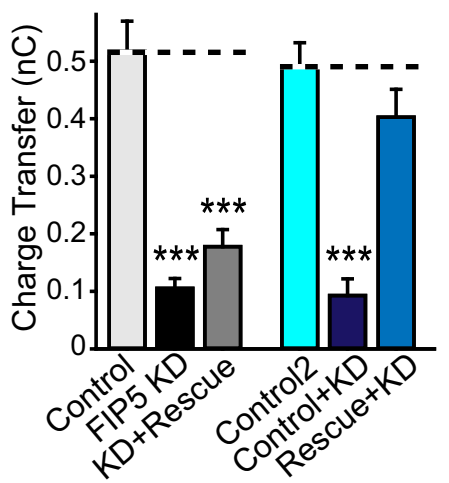

B
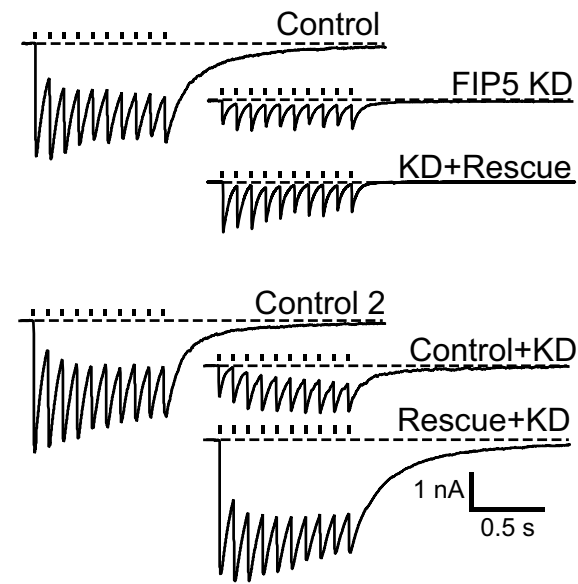

IPSCs evoked by $10 \mathrm{~Hz}$ stimulus trains

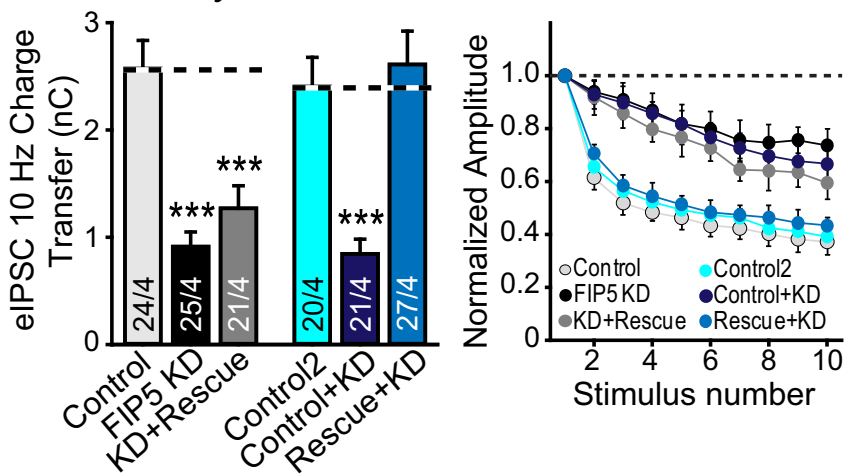

C

IPSCs evoked by hypertonic sucrose
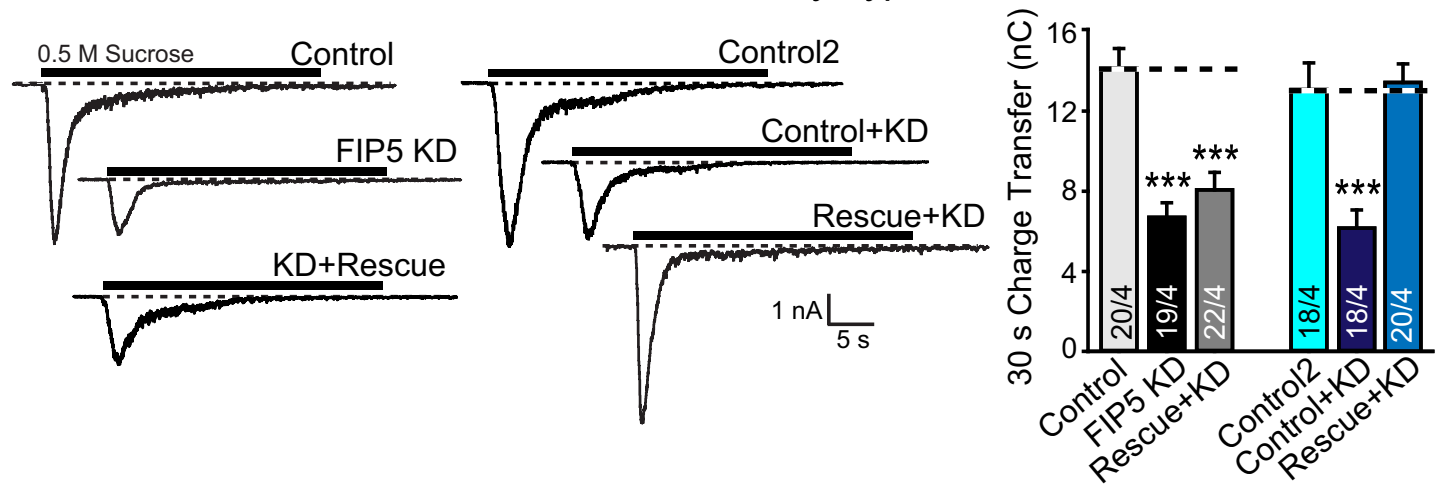

Figure 2. Characterization of inhibitory transmission after Rab11Fip5 shRNA knockdown. $\boldsymbol{A}$, Evoked IPSCs recorded in cultured hippocampal neurons are severely reduced by a Rab11Fip5 shRNA. Sample traces (left) and peak current amplitude and charge transfer during one action potential (right two panels) are shown. Notch marks in sample traces indicate the time of stimulation; the stimulation artifact has been removed for clarity. $\boldsymbol{B}$, eIPSC responses during a $10 \mathrm{~Hz}$ stimulus train. Sample traces (left), total charge transfer during the train (middle), and peak amplitudes for each stimulus normalized to the first peak (right) are shown. C, IPSCs triggered by a 30 s application of $0.5 \mathrm{M}$ sucrose, sample traces (left) and quantification of the charge transfer during the 30 s sucrose application (right). The timing of sucrose application is indicated by the black rectangle. Recordings are performed in the presence of TTX to block action potentials in addition to AP5 and CNQX that are used to isolate inhibitory currents. The number of cells/cultures recorded is indicated in each graph. Graphs represent mean \pm SEM. ${ }^{* *} p<0.001$ (one-way ANOVA).

lentiviral construct failed to rescue any of the observed phenotypes (Figs. $1 C, D, 2)$, suggesting that the observed effects are nonspecific.

In our lentivirus construct, shRNA expression is driven by a pol III promoter, whereas cDNA expression is driven by a pol II promoter. Thus, it is theoretically possible that the kinetics of the two promoters are different and could result in a scenario in which the KD takes effect before the rescue cDNA can be expressed. If the gene of interest plays a critical developmental func- tion during this time window, the lack of rescue could be explained by this brief potential KD during development. To eliminate such a possibility, we expressed the shRNA and the rescue construct from two different lentiviruses, and infected the cultures with the rescue lentivirus after 2 DIV, whereas infection with the KD virus was performed at 4 DIV (Fig. $1 A$ ). Surprisingly, this manipulation was able to fully rescue all the observed phenotypes (Figs. 1C,D, 2). 
A

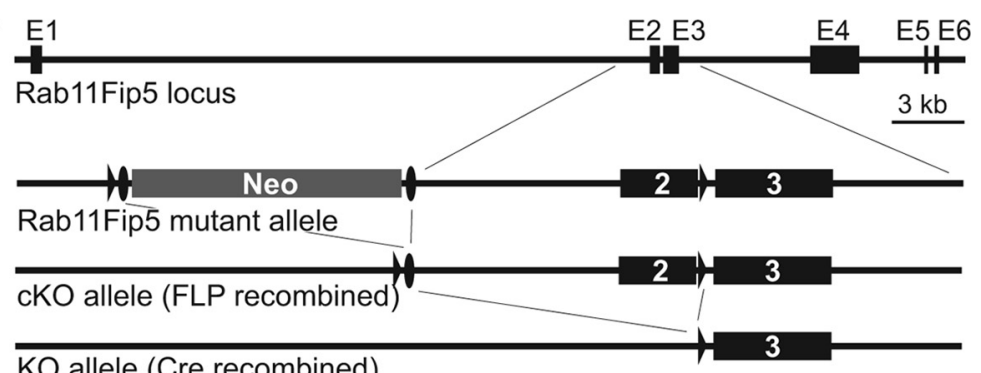

KO allele (Cre recombined)

B

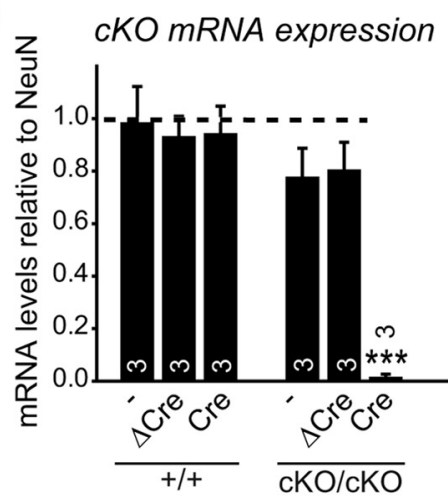

C

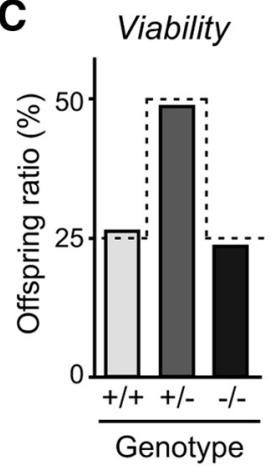

D

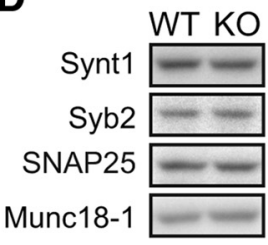

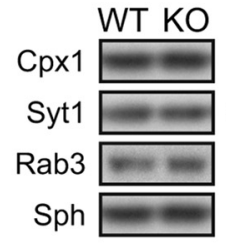

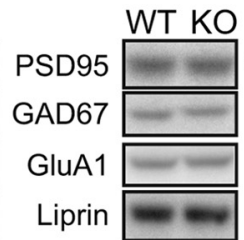

E

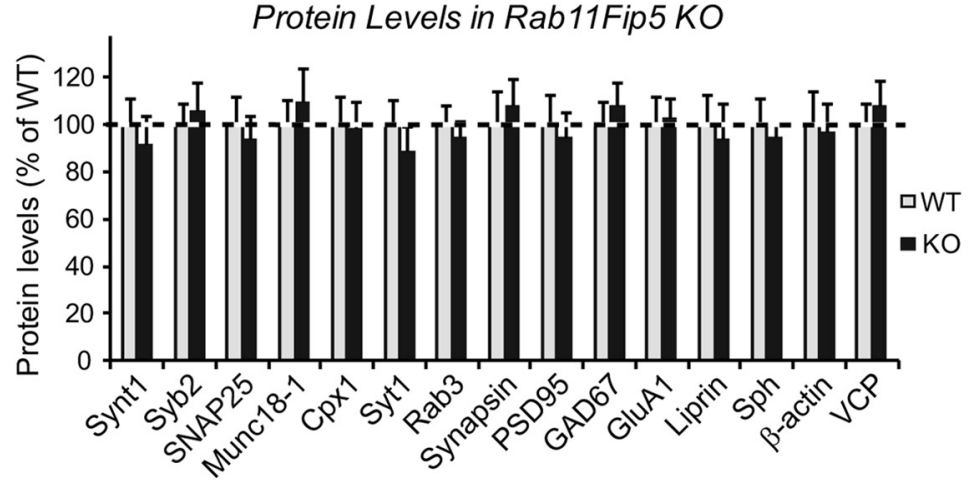

Figure 3. Rab11Fip5 K0 mice are viable and have normal synaptic protein levels. $\boldsymbol{A}$, Strategy for generating Rab11Fip5 conditional $\mathrm{KO}$ animals. The genomic locus is shown with exon 1 containing the ATG start site. loxP sites are indicated by triangles while frt sites by ovals. $\boldsymbol{B}$, mRNA expression levels are not altered in cultured hippocampal neurons from Rab11Fip5 w/w and cK0/cK0 littermates. Rab11Fip5 mRNA levels are normalized to those of NeuN. Three independent cultures were infected with no virus, a lentivirus carrying an inactive form of $\mathrm{Cre}(\Delta \mathrm{Cre})$, or a Cre virus, total RNA was harvested and assayed by qRT-PCR. C, Rab11Fip5 K0 alleles do not affect survival rates. Dashed line indicates expected ratio, which is not statistically different from that observed, $>100$ offspring were assessed. $\boldsymbol{D}$, Representative ${ }^{125} \mathrm{I}$ immunoblots of synaptic proteins from whole-brain lysates of Rab11Fip5 w/w and KO/KO littermates. Loading controls are $\beta$-actin and valosin-containing protein (VCP). E, Quantification of protein levels in immunoblots from three different littermate pairs shows no significant changes. $\boldsymbol{B}, \boldsymbol{E}$, Graphs represent mean \pm SEM. *** $p<0.001$.

Normally, the rescuing cDNA has to be recoded so as to be impervious to the shRNA. Taking advantage of this, we developed two quantitative PCR probes: one that recognizes only the endogenous Rab11Fip5 mRNA and a second that recognizes both the endogenous mRNA as well as the overexpressed cDNA. Using these probes, we confirmed by qPCR that the KD efficiency is similar in all conditions used (Fig. 1B). Thus, a nonspecific reversal of the KD of endogenous Rab11Fip 5 by the overexpression of the rescue cDNA, which may suppress the KD efficacy of the shRNAs, for example, by soaking up the entire microRNA processing machinery, cannot explain the rescue effect we observed.

\section{Generation of Rab11Fip5 conditional mutant mice}

Because the Rab11Fip5 KD phenotype was robust but was only able to be rescued using a nonconventional protocol, we generated conditional knock-out (KO) animals by "floxing" the second exon of Rab11Fip5 (Fig. 3A). KO animals were born at expected Mendelian frequencies and had normal viability (Fig. $3 C$ ). To confirm that the targeting strategy was successful, hippocampal neurons from wild-type and knock-in animals were cultured and infected with lentiviruses carrying Cre recombinase or a catalytically inactive form of Cre $(\Delta$ Cre $)$. No differences in Rab11Fip5 mRNA levels in uninfected or $\Delta$ Cre-infected cells between wild-type and $\mathrm{KI}$ cultures were seen (Fig. 3B), suggesting that the targeted locus still expresses Rab11Fip5 at levels similar to the endogenous gene. However, addition of Cre virus almost totally abolished Rab11Fip5 mRNA expression (Fig. 3B). To examine whether synapses were grossly normal in $\mathrm{KO}$ animals, we measured the levels of several presynaptic and postsynaptic proteins from whole-brain lysates by quantitative immunoblotting with ${ }^{125} \mathrm{I}$ iodinated secondary antibodies and found no significant differences (Fig. 3D,E). As measured by qPCR, the levels of Rab11Fip1 and Rab11Fip2, the two homologs of Rab11Fip5, were not altered in Rab11Fip5 KO animals (data not shown), indicating that removal of Rab11Fip does not alter the expression of these closely related genes, which could compensate for the lack of Rab11Fip5.

\section{Rab11Fip5 KO mice display facilitation} in contextual fear extinction

Because Rab11Fip5 KO mice had normal viability, we tested mutant and wild-type male littermate siblings in a series of behavioral tasks to uncover any potential cognitive deficits that arise from lack of Rab11Fip5. To ensure that Rab11Fip5 KO animals do not have altered locomotion, they were monitored for $60 \mathrm{~min}$ in an open-field test. No differences in baseline locomotion were found between WT and Rab11Fip $5 \mathrm{KO}$ littermates in the total distance traveled (Fig. 4I). Rab11Fip5 KO mice also displayed normal levels of anxiety based on the time spent and distance traveled in the center of the arena (Fig. 4J,K). 

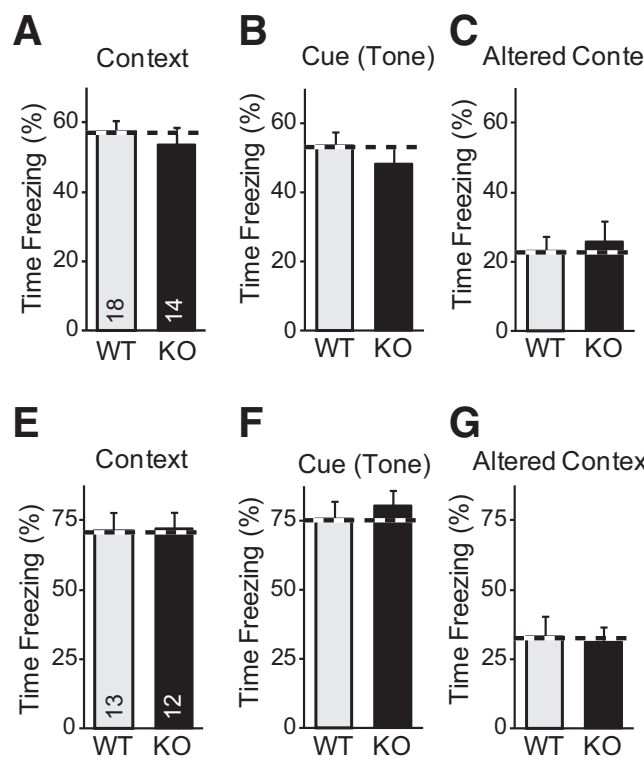

$\mathbf{F}$

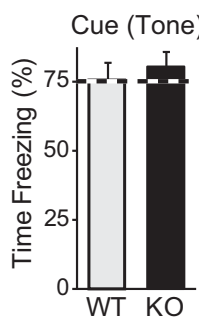

G

Altered Context

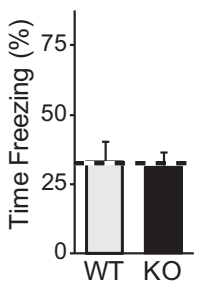

$\mathbf{J}$

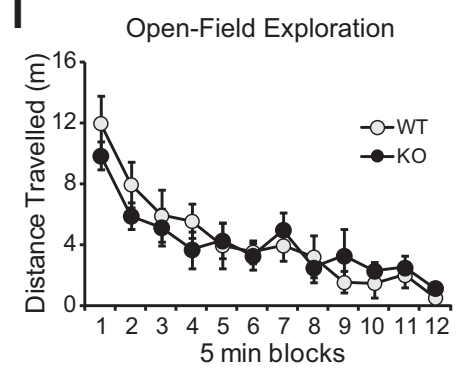

\section{D}

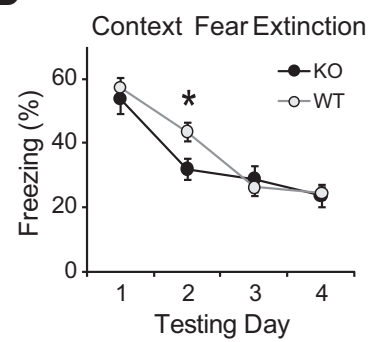

H
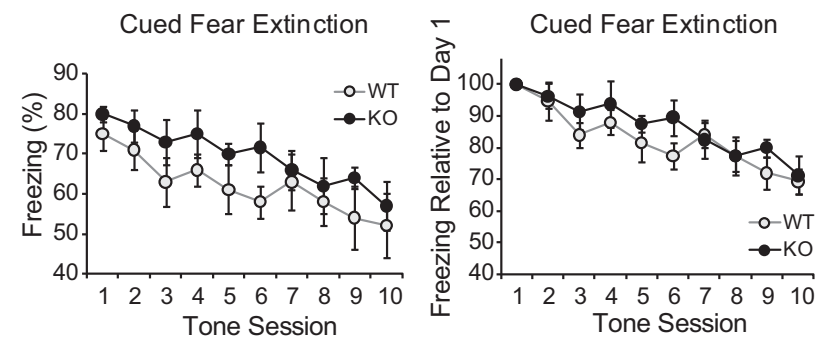

M
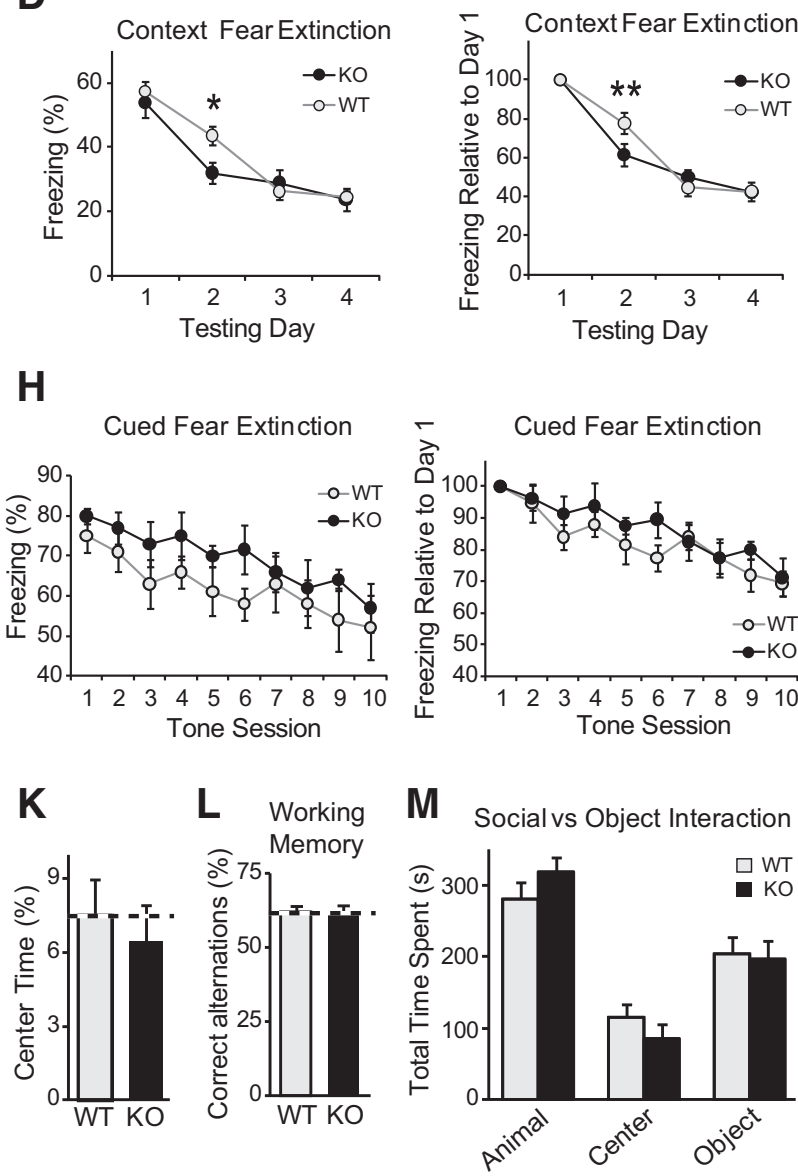

Figure 4. Rab11Fip5 K0 facilitates contextual fear extinction. $\boldsymbol{A}-\boldsymbol{H}$, Male, littermate Rab11Fip5 WT and K0 animals after fear conditioning show no differences in freezing rates during exposure to context $(\boldsymbol{A}, \boldsymbol{E})$, tone $(\boldsymbol{B}, \boldsymbol{F})$, or an altered context $(\boldsymbol{C}, \boldsymbol{G})$. Reexposure to the context results in fear extinction, which is facilitated in Rab11Fip5 $\mathrm{K} 0$ mice only for the second day trial $(\boldsymbol{D})$. Fear extinction during multiple exposures to the conditional stimulus (tone) was unaltered in the $\mathrm{KO}$ mice $(\boldsymbol{H}) . \boldsymbol{I}-\boldsymbol{K}$, As assayed by an open-field test, wild-type and mutant mice had no statistically significant differences in baseline locomotion $(\boldsymbol{I})$ and anxiety $(\boldsymbol{J}, \boldsymbol{K})$. $\boldsymbol{L}$, The number of spontaneous alternations in a Y-maze test, a measure of short-term memory, was undistinguishable between WT and $K 0$ Rab11Fip5 mice. $M$, Rab11Fip5 $\mathrm{K} 0$ mice showed normal responses in a social preference task, favoring the animal chamber versus the object chamber at the same rate as wild-type littermates. In all panels, graphs represent mean \pm SEM. Statistical significance is assessed by two-way repeated-measures ANOVA for the extinction trials, one-way ANOVA in the other cases: ${ }^{*} p<0.05$; ${ }^{* *} p<0.01$.

To test short-term memory, we assayed spontaneous alterations in a Y-maze, defined as the number of consecutive entries into three different arms, and found no differences between the two mouse groups (Fig. $4 L$ ). In addition, because Rab11Fip5 has been linked to autism spectrum disorders in humans, we tested Rab11Fip5 KO animals in a social preference task. In a three-chambered testing area, both WT and mutant animals preferentially spent time in the chamber housing a mouse as opposed to the chamber housing a novel object, and no differences between the groups were observed (Fig. 4M).

Contextual fear-conditioning is a well-characterized hippocampus-dependent learning paradigm. The hippocampus is required for formation and retrieval of context-fear associations (Holland and Bouton, 1999) as well as for context-dependent encoding of fear extinction (Corcoran et al., 2005), which is also a learning process. Testing of littermate WT and Rab11Fip5 KO animals yielded no differences in learning as freezing in response to the training context, the training tone, or a separate context was the same in the two groups $24 \mathrm{~h}$ after conditioning (Fig. $4 A-C)$. Extinction trials were performed by continuing to expose mice to the training context for 3 more consecutive days. Analysis with two-way repeated-measures ANOVA showed a significant difference in the interaction of genotype $\times$ day of assessment $\left(F_{(1,30)}=\right.$ 4.66, $p=0.004$ for raw data, and $F_{(1,30)}=2.98, p=0.036$ for data normalized to the first day freezing rates). Comparisons for differences within each day uncovered a significant difference only for the day 2 exposure (i.e., the first extinction trial), with Rab11Fip5 KO mice exhibiting an enhanced fear extinction rate (Fig. $4 D ; p=0.014$ for raw data and $p=0.002$ for normalized data).

To determine whether the facilitated extinction phenotype extended to tone-triggered freezing, a task thought to rely mostly on the amygdala (Quirk and Mueller, 2008), a second experiment was performed with another set of conditioned mice. As before, no differences in freezing rates were observed $24 \mathrm{~h}$ after conditioning (Fig. 4E-G). Extinction trials were performed by continuing to expose mice to the conditional stimulus (the tone presented in a context different from the training one) for 9 more days. No differences in extinction rates were observed (Fig. 4H).

These behavioral results suggest that the Rab11Fip5 KO does not cause major impairments in fear conditioning, locomotion, anxiety, short-term memory, and sociability in mice but appears to facilitate contextual fear extinction.

\section{Cultures of Rab11Fip5 KO neurons display grossly normal synaptic function}

To test whether lack of Rab11Fip5 alters basal synaptic function, we cultured hippocampal neurons from Rab11Fip5 conditional KO 
mice and infected these neurons with a control virus carrying inactive Cre, a virus carrying Cre recombinase (which yields a culture lacking Rab11Fip5), or a lentivirus carrying both Cre and a Rab11Fip5 rescuing construct. The same electrophysiological measurements as for the shRNA characterization (Fig. 1) were performed. In contrast to the shRNA KD phenotypes, we found no changes in evoked IPSCs (Fig. $5 A, B$ ) or inhibitory ready releasable pool size (Fig. 5C). Evoked EPSC amplitudes were also unaltered in Cre-infected neurons (Fig. 5D). Recording of spontaneous, miniature events showed no differences in amplitude or frequency for inhibitory (Fig. 5E) and excitatory (Fig. 5F) currents.

These results contradict our observations with shRNA KD manipulations. Therefore, we tested whether the shRNA KD would affect neurotransmission in the Rab11Fip5 KO background. Because application of Cre abolishes Rab11Fip5 mRNA expression in Rab11Fip5 cultures, further knockdown by the shRNA should be impossible. Thus, any observed phenotypes would suggest that the shRNA has nonspecific off-target effects. Indeed, we found that infection by the shRNA-carrying virus in addition to the Cre virus resulted in reduced evoked IPSCs and EPSCs (Fig. 5G), compared with infection by a Cre virus alone. As expected, Rab11Fip 5 mRNA levels were severely reduced in both the Cre and $\mathrm{KD}+\mathrm{Cre}$ conditions (Fig. $5 H$ ). Together, our results suggest that genetic deletion of Rab11Fip5 does not affect evoked or spontaneous transmission in cultured neurons and that the effects of the Rab11Fip5 shRNA were due to off target effects.

\section{Rab11Fip5 is required for LTD but dispensable for LTP}

Our results thus far suggest that Rab11Fip5 is not required for basal synaptic transmission in cultured neurons. To further investigate possible postsynaptic functions of Rab11Fip5, we next examined NMDAR-dependent LTP at Schaffer collateral-CA1 synapses using extracellular field recordings in the CA1 region of acute hippocampal slices from Rab11Fip5 heterozygous (control) and homozygous (KO) mice (Fig. 6). The magnitude of LTP induced by tetanic stimulation was unchanged in Rab11Fip5 KO mice (Fig. 6A). We also performed LTP experiments during whole-cell patch-clamp recordings from CA1 pyramidal neurons, and again the magnitude of LTP was unchanged in Rab11Fip5 KO mice (Fig. 6B). These results demonstrate that Rab11Fip5 is not required for the induction or expression of LTP. In marked contrast, NMDAR-dependent LTD at Schaffer collateral-CA1 synapses (Fig. 7B), which also involves NMDARinduced trafficking of AMPARs, was on average absent in slices prepared from Rab11Fip5 $\mathrm{KO}$ mice in both extracellular recording experiments (Fig. $7 A ; p<0.05$, control, $71 \pm 11 \%, n=5$; $\mathrm{KO}$, $117 \pm 13 \%, n=5)$ and during whole-cell recordings from CA1 pyramidal neurons (Fig. $7 C$; $p<0.05$, control, $52 \pm 6 \%, n=8$; $\mathrm{KO}, 101 \pm 6 \%, n=8)$.

\section{Rab11Fip5 is not required for basal transmission in CA1 pyramidal cells in acute slices}

To determine whether Rab11Fip5 plays a specific role in NMDAR-dependent LTD, we performed several additional measurements of basal excitatory synaptic transmission in acute slices. Input-output assays in which the initial slope of the fEPSP is plotted as a function of the presynaptic fiber volley amplitude revealed no detectable effects in the Rab11Fip5 KO slices (Fig. $8 A$ ). We examined this issue further by performing whole-cell recordings of miniature AMPAR-mediated EPSCs. Neither mEPSC amplitude nor frequency was affected in Rab11Fip5 KO mice (Fig. 8B). These results suggest that basal AMPAR-mediated synaptic transmission, and therefore basal AMPAR trafficking, is not affected in Rab11Fip5 KO mice. To determine whether the lack of Rab11Fip5 influenced basal NMDAR-mediated synaptic transmission, we calculated the ratio of NMDAR- to AMPARmediated EPSCs (Kauer and Malenka, 2007). This ratio was also not affected by genetic deletion of Rab11Fip5 (Fig. 8C). Consistent with Rab11Fip5 acting postsynaptically, no effect was detected on paired-pulse ratios, a measure of changes in presynaptic function (Fig. 8D). Thus, consistent with the results in cultured neurons, Rab11Fip5 is not required for maintaining basal excitatory synaptic transmission.

\section{Rab11Fip5 is required for NMDA-triggered chemical LTD in neuronal cultures}

The primary mechanism that accounts for NMDAR-dependent LTD is the NMDAR-triggered endocytosis of AMPARs and their subsequent intracellular retention (Malenka and Bear, 2004; Huganir and Nicoll, 2013). This process can be recapitulated in cultured neurons by applying NMDA, which within a few minresults in the endocytosis of surface AMPARs, a protocol often termed chemical LTD (cLTD) (Carroll et al., 1999; Lissin et al., 1999; Lee et al., 2004; Bhattacharyya et al., 2009; Mao et al., 2010). Furthermore, manipulations that impair LTD in acute slices commonly impair cLTD in culture (Beattie et al., 2000; Bhattacharyya et al., 2009; Citri et al., 2010; Jurado et al., 2010), suggesting that the two processes share a similar machinery. We therefore examined the role of Rab11Fip5 in the endosomal trafficking of AMPARs using CLTD induction in cultured neurons.

Staining for the AMPAR subunit GluA1 and the postsynaptic protein PSD-95 confirmed that Rab11Fip5 KO cultures had normal density of GluA1 synaptic puncta as well as normal GluA1 puncta size, a measure of synaptic size (Fig. 9A). Together, these observations suggest that basal GluA1 receptor levels are not altered by the $\mathrm{KO}$, which is in agreement with the lack of a phenotype in basal transmission (Fig. 8). The fraction of internalized GluA1 receptors $15 \mathrm{~min}$ following NMDA application (Fig. 9B) (Bhattacharyya et al., 2009) was increased by almost twofold in $\Delta$ Cre-infected Rab11Fip 5 cKO cultures but remained unchanged over baseline internalized GluA1 receptors in Cre-infected cultures (Fig. 9C; $p<0.01, \Delta$ Cre, $1.8 \pm 0.12, n=6$; Cre, $1.07 \pm 0.11$, $n=6)$. To determine whether this defect arises from lack of proper internalization as opposed to the inability to retain internalized receptors in endosomal compartments, a shorter chase time was analyzed. After $5 \mathrm{~min}$, internalization of GluA1 receptors was not significantly altered in the absence of Rab11Fip5 (Fig. $9 D ; p=0.46, \Delta$ Cre, $1.73 \pm 0.20, n=6$; Cre, $1.52 \pm 0.20, n=$ 6). Thus, consistent with its requisite role in NMDAR-dependent LTD, Rab11Fip5 is required for the net increase in internalized surface AMPARs following NMDA application in cultured neurons, and it acts primarily by preventing recycling back to the plasma membrane of internalized receptors.

\section{Discussion}

AMPARs are responsible for most basal synaptic transmission at excitatory synapses. These receptors can be inserted or removed from synapses in response to neuronal activity, leading to longlasting changes in synaptic strength, such as LTP and LTD (Malenka and Bear, 2004; Huganir and Nicoll, 2013). The subunit composition and phosphorylation state of AMPARs and their interaction with scaffolding proteins are important for AMPAR localization, stabilization, and membrane trafficking (Sheng and Lee, 2001; Malinow and Malenka, 2002; Huganir and Nicoll, 2013). This complex regulation of AMPAR trafficking 
A
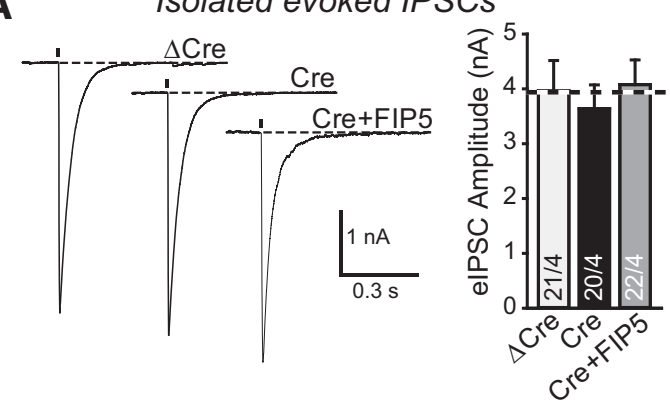

B IPSCs evoked by $10 \mathrm{~Hz}$ stimulus trains
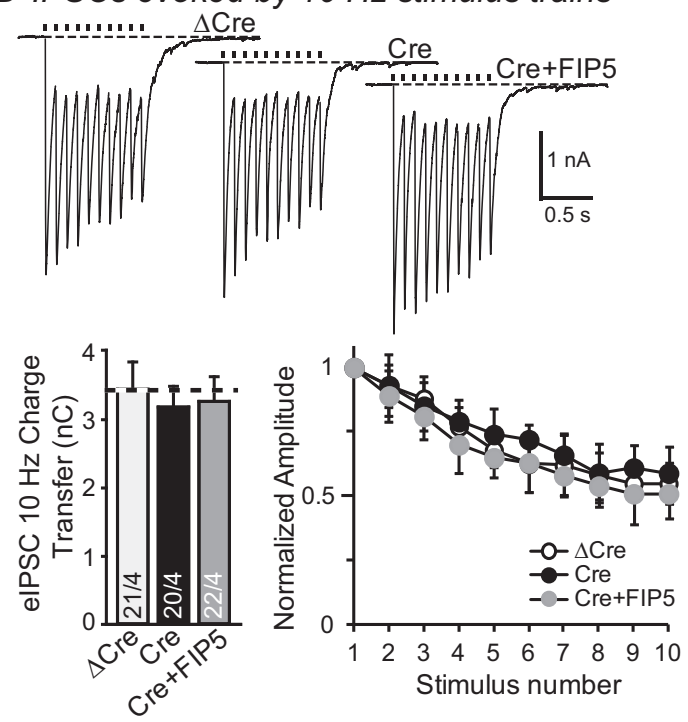

C IPSCs evoked by hypertonic sucrose
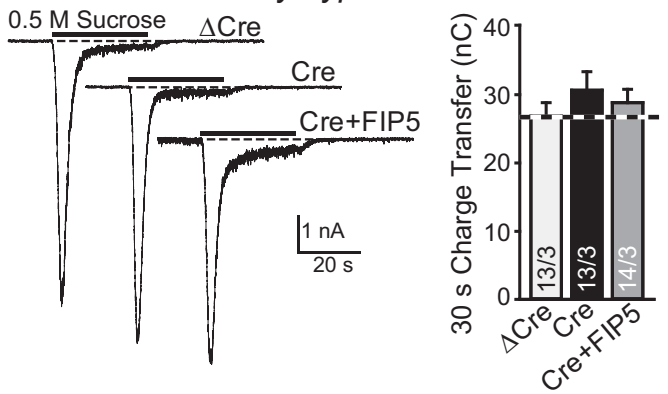

D

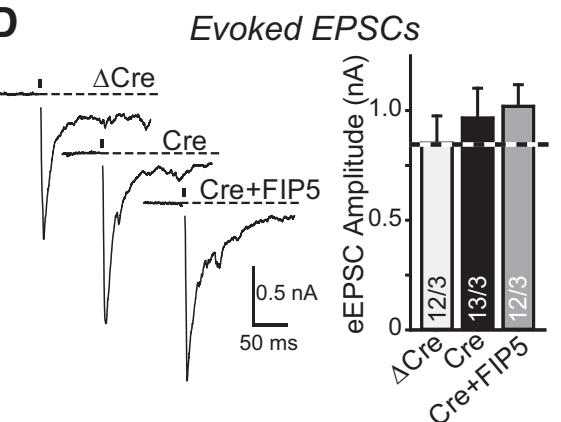

E $\triangle$ Cre $\quad$ mIPSCs

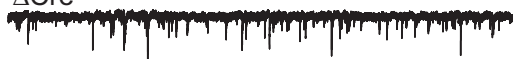
Cre

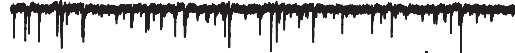
Cre+FIP5
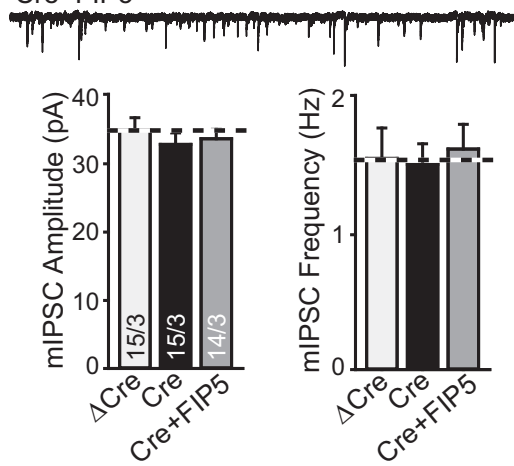

$\mathbf{F}$
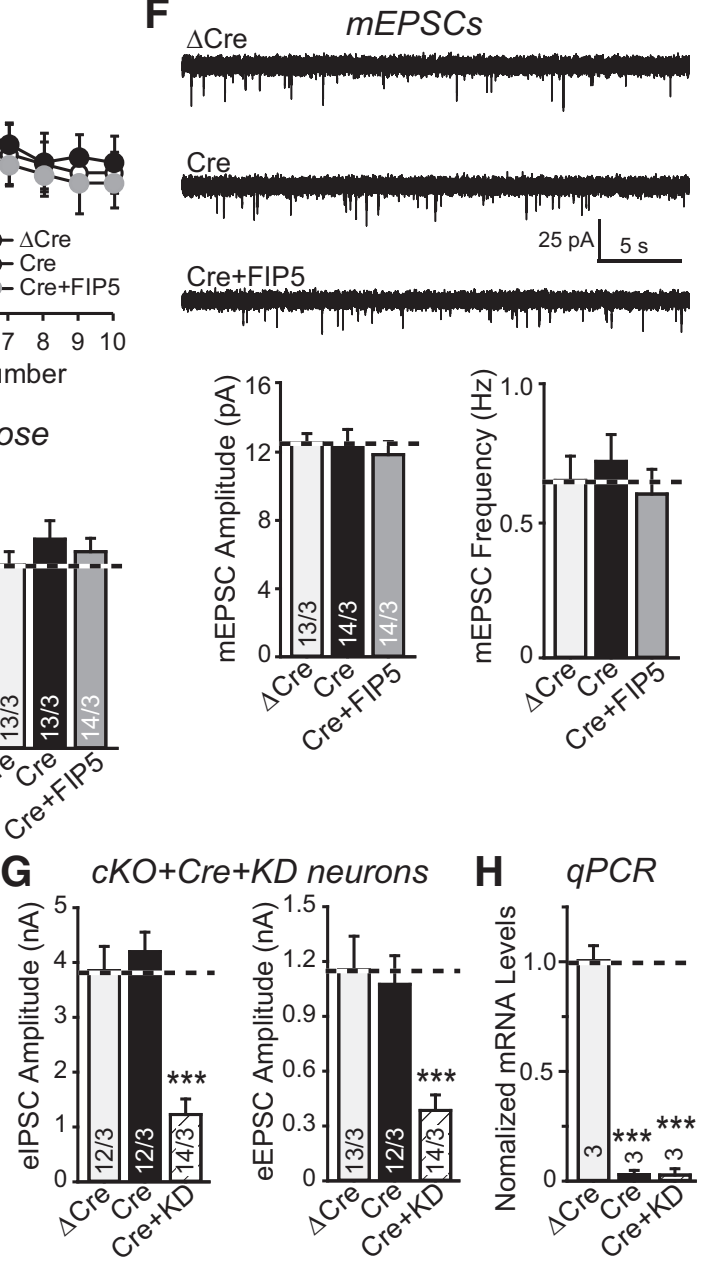

Figure 5. Rab11Fip5 K0 cultures show no major electrophysiological changes. A, Evoked IPSCS recorded from Rab11Fip5 cK0-cultured hippocampal neurons: sample traces (left) and peak current amplitude (right). The conditions in this and subsequence panels are as follows: lentivirus carrying a catalytically inactive $\mathrm{Cre}(\Delta \mathrm{Cre})$, Cre lentivirus (Cre), and a single lentivirus carrying Cre and a Rab11Fip5 rescue cDNA (Cre+Fip5). B, elPSC responses during a $10 \mathrm{~Hz}$ stimulus are not altered by Rab11Fip5 K0. Sample traces (top), total charge transfer during the train (bottom left), and normalized peak amplitudes (bottom right) are shown. C, Sucrose-triggered IPSCs are also unaffected by the K0: sample traces (left) and quantification of the chargetransfer during the 30 s sucrose application (right). D, Evoked EPSCsin Rab11Fip5 cultures: traces (left) and peak amplitude (right). Because recordings are performed in mixed cultures, network activity is observed soon after the first stimulus. $\boldsymbol{E}, \boldsymbol{F}, \operatorname{Spontaneous} \mathrm{mIPSCS}(\boldsymbol{E})$ and $\mathrm{mEPSCs}(\boldsymbol{F})$ have normal amplitude and frequency in Rab11Fip5 cKO cultures. $\mathbf{G}, \boldsymbol{H}$, The Rab11Fip5 shRNA acts in a nonspecific manner. Evoked IPSCS (left) and EPSCS (right) recorded from cKO cultures (G) infected with two viruses (carrying Cre and the KD shRNA) are reduced compared with the Crevirus-infected cultures. The phenotype is likely not due to the Rab11Fip5 mRNA levels because the mRNA levels are similar in the two conditions $(\boldsymbol{H})$. The number of cells/cultures recorded is indicated in each graph. Graphs represent mean \pm SEM. ${ }^{* * *} p<0.001$ (one-way ANOVA). 

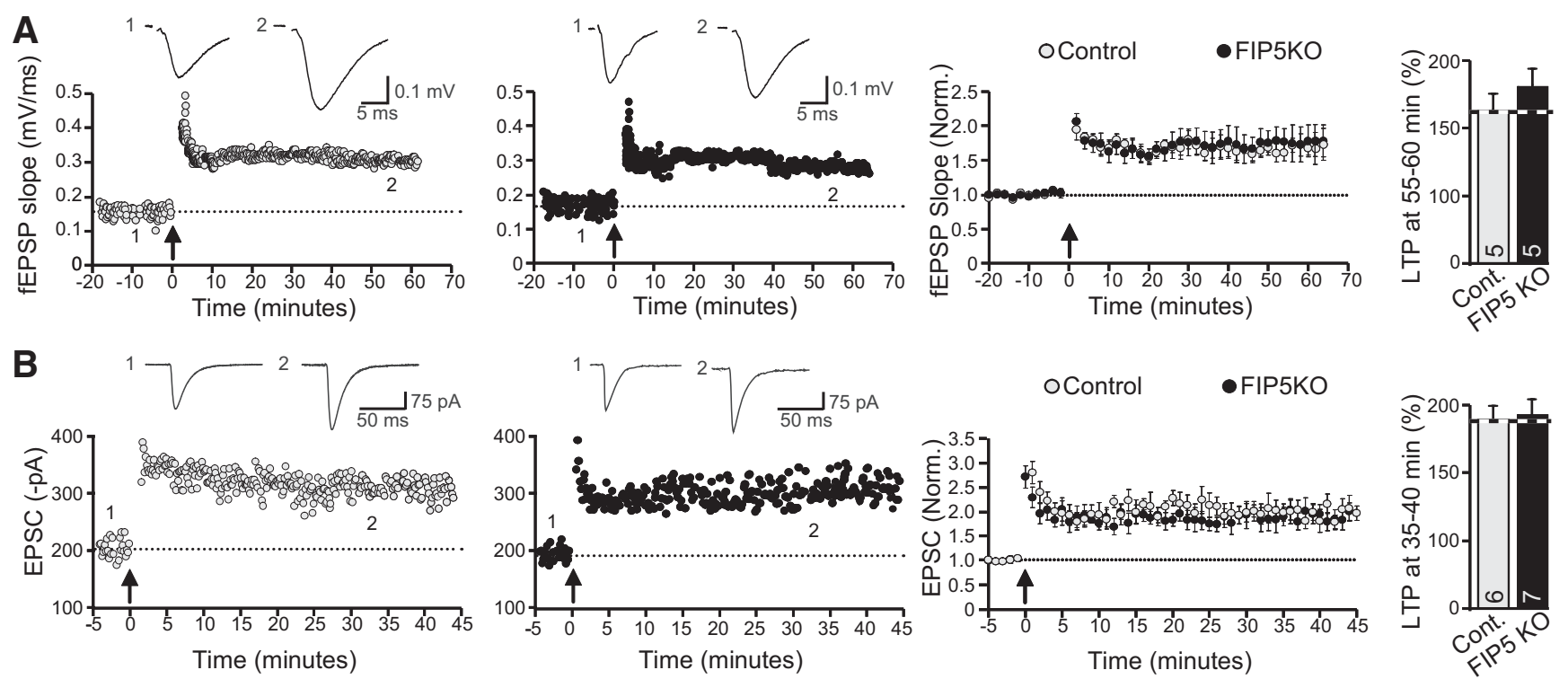

Figure 6. LTP is unchanged in Rab11Fip5 KO mice. $A$, Sample experiments (left two panels) and summary graphs (right two panels) of LTP obtained by extracellular field recordings in stratum radiatum of acute hippocampal slices from heterozygous (control) and Rab11Fip5 KO mice (control, $168 \pm 7 \%, n=5 ; \mathrm{KO}, 175 \pm 17 \%, n=5$ ). Arrow indicates the time of tetanic stimulation. Sample-averaged fEPSPs during the baseline (1) and 50 min after LTP induction (2) are shown above the sample experiments. B, Sample experiments (left two panels) and summary graphs (right two panels) of $L T P$ obtained by whole-cell patch-clamp recordings of CA1 pyramidal neurons in acute hippocampal slices from heterozygous (control) and Rab11Fip5 K0 mice (control, $197 \pm 14 \%$, $n=6, K 0,200 \pm 18 \%, n=7$ ). Arrow indicates the time of tetanic stimulation. Sample-averaged EPSCs during the baseline (1) and 30 min after LTP induction (2) are shown above the sample experiments. The number of slices $(\boldsymbol{A})$ or cells $(\boldsymbol{B})$ recorded is indicated in each graph. Graphs represent mean \pm SEM. No significant statistical differences were found using Student's $t$ test.

suggests highly structured dynamics in the intracellular transport of these receptors. Indeed, endosomal trafficking is important for the synaptic sorting of AMPARs, whose functional compartmentalization is likely governed by multiple GTPases of the Rab family (Gerges et al., 2004; Brown et al., 2005, 2007; Wang et al., 2008).

In the present study, we investigated the synaptic function of Rab11Fip5, a Rab11 effector, using two approaches: an shRNAmediated KD and a genetically produced KO. We first examined the effect of the Rab11Fip5 shRNA-mediated KD on basal transmission, analyzing evoked and miniature inhibitory transmission in hippocampal neurons. The Rab11Fip5 KD produced a very significant impairment in inhibitory transmission that suggested a major presynaptic function of Rab11Fip5. Initial attempts to rescue this effect using standard molecular replacement strategies (Xu et al., 2008; Ahmad et al., 2012; Bacaj et al., 2013; Jurado et al., 2013) were unsuccessful, but swapping the order of infections such that the rescue construct was infected before the shRNA knockdown achieved full rescue (Figs. 1, 2). An overexpressed rescue cDNA might act not by restoring the protein levels, but by interfering with the KD of the endogenous target mRNA simply by "soaking up" the shRNA. Because the cDNA rescued only when "prerescued," we verified that this rescue strategy did not interfere with the shRNA-mediated KD of the endogenous Rab11Fip5 mRNA. However, the endogenous Rab11Fip5 mRNA remained fully suppressed even in the presence of the overexpressed cDNA (Fig. 1B). Together, these data suggested to us, erroneously as we realized later, that Rab11Fip5 performs a major role in neurotransmitter release. Because Rab11 is present on synaptic vesicles (Khvotchev et al., 2003) and has been shown to regulate exocytosis of secretory vesicles in PC12 cells (Khvotchev et al., 2003), a role for Rab11Fip5 in release appeared plausible, but to independently test this role, we generated Rab11Fip5 conditional KO mice (Fig. 3).

Surprisingly, examination of Rab11Fip5 KO mice showed that basal synaptic transmission in general, and neurotransmitter re- lease in particular, were unaltered after deletion of Rab11Fip5, both in cultured neurons and in acute slices. How can we account for the discrepancy between the $\mathrm{KO}$ and $\mathrm{KD}$ results for basal synaptic transmission? Because the experiments performed in cultured neurons analyzed a conditional KO of Rab11Fip5, the lack of the phenotype in the KO cannot be accounted for by an unspecified developmental compensation: the time-frame of Rab11Fip5 inactivation is similar for the $\mathrm{KD}$ and the $\mathrm{cKO}$, and compensation should have occurred under both conditions. The simplest and most plausible explanation for these observations is that the shRNA-mediated KD is subject to off-target effects that are unrelated to Rab11Fip5, even though they can be rescued by overexpression of Rab11Fip5. Notably, we obtained rescue only by expressing the rescue cDNA before the KD shRNAs, which already suggests a potential problem. It is likely that the "prerescuing" protocol was successful because the overexpressed rescue mRNA, which although mutated in several base pairs, must still retain some affinity for the shRNA sequence and likely neutralizes a fraction of the shRNAs, thus reducing off-target effects. However, this could obviously also occur during regular rescue experiments, and it may be advisable that, when feasible, shRNA-mediated KD experiments be controlled not only by performing rescue experiments, but also by using multiple independent shRNAs.

Because the Rab11Fip5 KO mice exhibited normal basal transmission, we explored a possible role in regulated AMPAR trafficking during long-term plasticity. Our experiments revealed that LTP is unchanged at the Schaffer collateral-CA1 synapses in Rab11Fip5 KO mice. Rab11 has been implicated in trafficking of AMPARs from recycling endosomes (REs) to the plasma membrane during LTP (Park et al., 2004). It has also been suggested that a related family member, Rab11Fip2, can bind in a calciumdependent manner to the molecular motor myosin $\mathrm{Vb}$ and therefore may act as a mediator of Rab11-dependent trafficking of AMPARs during LTP (Wang et al., 2008). Rab11Fip2 and 

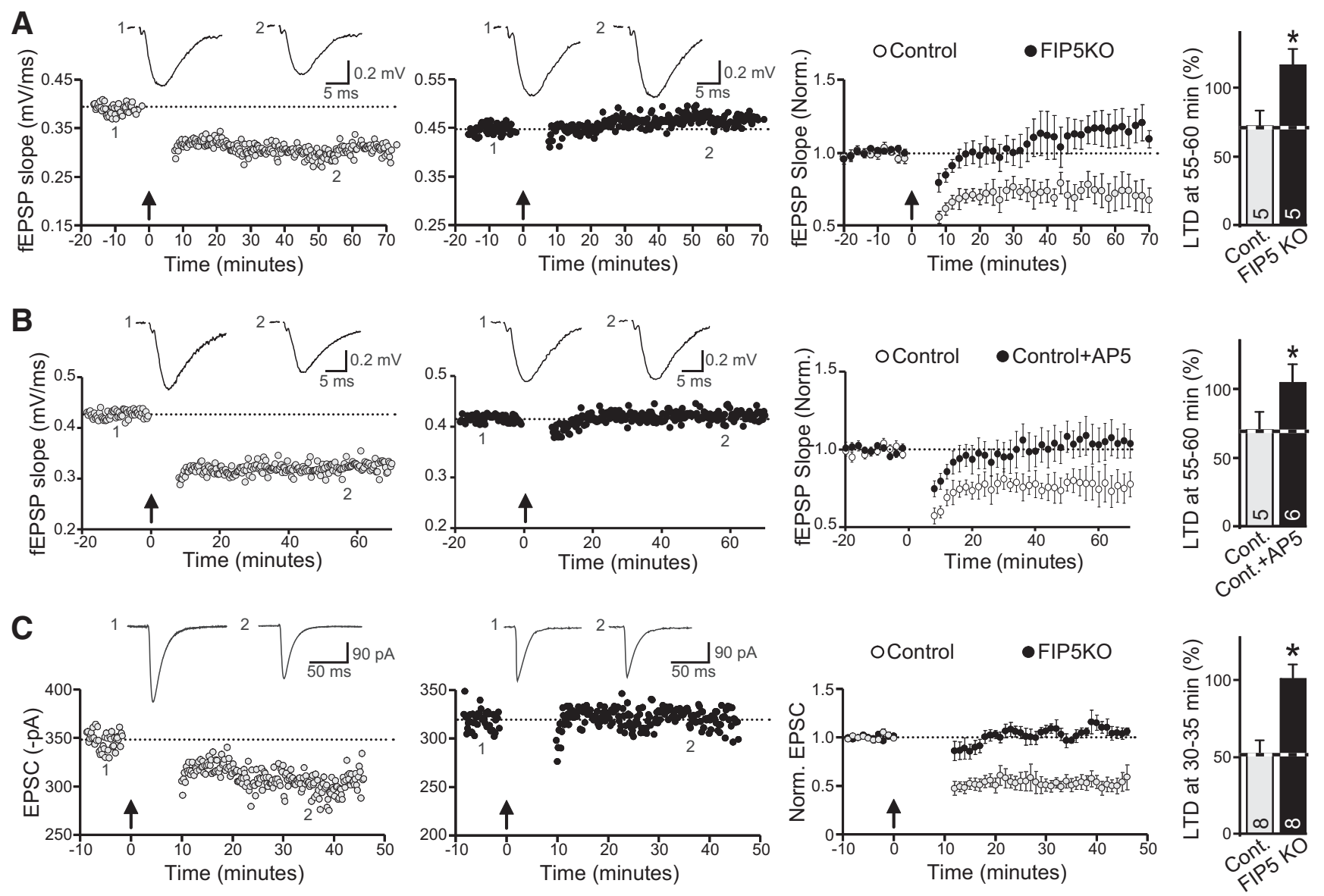

Figure 7. LTD is impaired in Rab11Fip5 K0 mice. A, Sample experiments (left two panels) and summary graphs (right two panels) of LTD obtained by extracellular field recordings in stratum radiatum of acute hippocampal slices from heterozygous (control) and Rab11Fip5 $\mathrm{KO}$ mice. Arrow indicates the time of onset of LTD induction stimulation. Sample-averaged fEPSPs during the baseline (1) and 50 min after LTD induction (2) are shown above the sample experiments. $\boldsymbol{B}$, LTD induction requires NMDA receptor activity. Same as $\boldsymbol{A}$, but LTD was induced in Rab11Fip5 heterozygous animals, in the absence (Control) or presence (Control + AP5) of AP5 to block NMDA receptor. C, Sample experiments (left two panels) and summary graphs (right two panels) of LTD obtained by whole-cell patch-clamp recordings of CA1 pyramidal neurons in acute hippocampal slices from heterozygous (control) and Rab11Fip5 KO mice. Arrow indicates the time of onset of LTD induction stimulation. Sample-averaged EPSCs during the baseline (1) and 30 min after LTD induction (2) are shown above the sample experiments. The number of slices $(\boldsymbol{A}, \boldsymbol{B})$ or cells $(\boldsymbol{C})$ recorded is indicated in each graph. Graphs represent mean \pm SEM. ${ }^{*} p<0.05$ (Student's $t$ test).

Rab11Fip5 have been found in overlapping compartments (Baetz and Goldenring, 2013) and might compensate for each other. Because Rab11Fip5 has been shown to regulate trafficking of many other cargo from the recycling endosomes to the plasma membrane (e.g., insulin-induced translocation of GLUT4 in adipocytes) (Welsh et al., 2007) and glucose-induced translocation of insulin receptor in pancreatic $\beta$ cells (Sugawara et al., 2009), it is surprising that LTP, which requires activity-induced trafficking of AMPARs from RE to the plasma membrane, was unchanged. However, potential compensation by Rab11Fip2 could explain the lack of any change in LTP in Rab11Fip5 KO slices. It will be interesting to test whether deletion of Rab11Fip2 alone or in combination with Rab11Fip5 produces a change in LTP.

The most notable result in our present study is that Rab11Fip5 is required for LTD (Fig. 7) and the net internalization of AMPARs during chemically induced LTD (Fig. $9 C, D$ ). This is a first demonstration that a Rab11Fip acts as a critical regulator of activity-induced trafficking in the postsynaptic compartment during LTD. Moreover, this lack of LTD was accompanied by a measurable acceleration of contextual fear extinction (Fig. 4D). These data are consistent with previous work that pinpoints the endocytosis of AMPARs as a key mechanism for contextual memory consolidation (Rao-Ruiz et al., 2011). Indeed, it has been proposed that an initial phase of synaptic depression, during which the memory returns to a labile state, is necessary for the subsequent process of reconsolidation.

Following the activation of NMDARs during LTD induction, AMPARs undergo intricate trafficking patterns and are dynamically allocated to different compartments. The internalization of these receptors from the plasma membrane to early endosomes is initiated by Rab5 (Bucci et al., 1992; Brown et al., 2005). Endocytosed receptors can be shuttled back to the cell surface through the Rab4 "fast" recycling pathway (van der Sluijs et al., 1992; Sheff et al., 1999), or sent to recycling endosomes via Rab11 (Brown et al., 2007). Here a decision is made to recycle receptors back to the surface via a Rab11 and Rab8 "slow" pathway (Brown et al., 2007) or to deliver receptors to late endosomes and, later, to the lysosome for degradation through Rab7 (Press et al., 1998; Fernández-Monreal et al., 2012). Interestingly, Rab11 is localized not only on REs, but has also been found on tubular extensions of early endosomes (Wilcke et al., 2000). It is therefore appropriately situated to mediate transfer of cargo from early endosomes to REs. It is possible that Rab11Fip5 acts as an adaptor at this step and directs the AMPARs to the slow pathway proceeding through REs where proteins, such as PICK1, cause their intracellular retention leading to LTD (Citri et al., 2010). It can be envisioned 
A
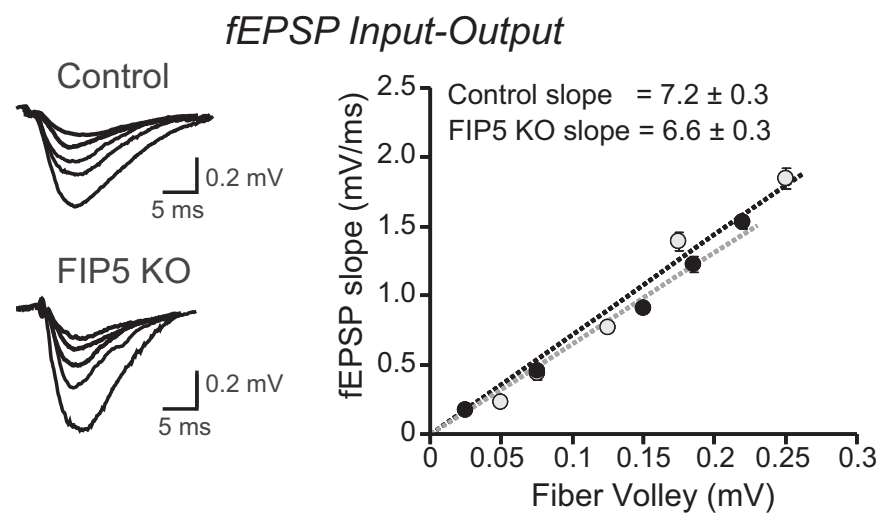

B
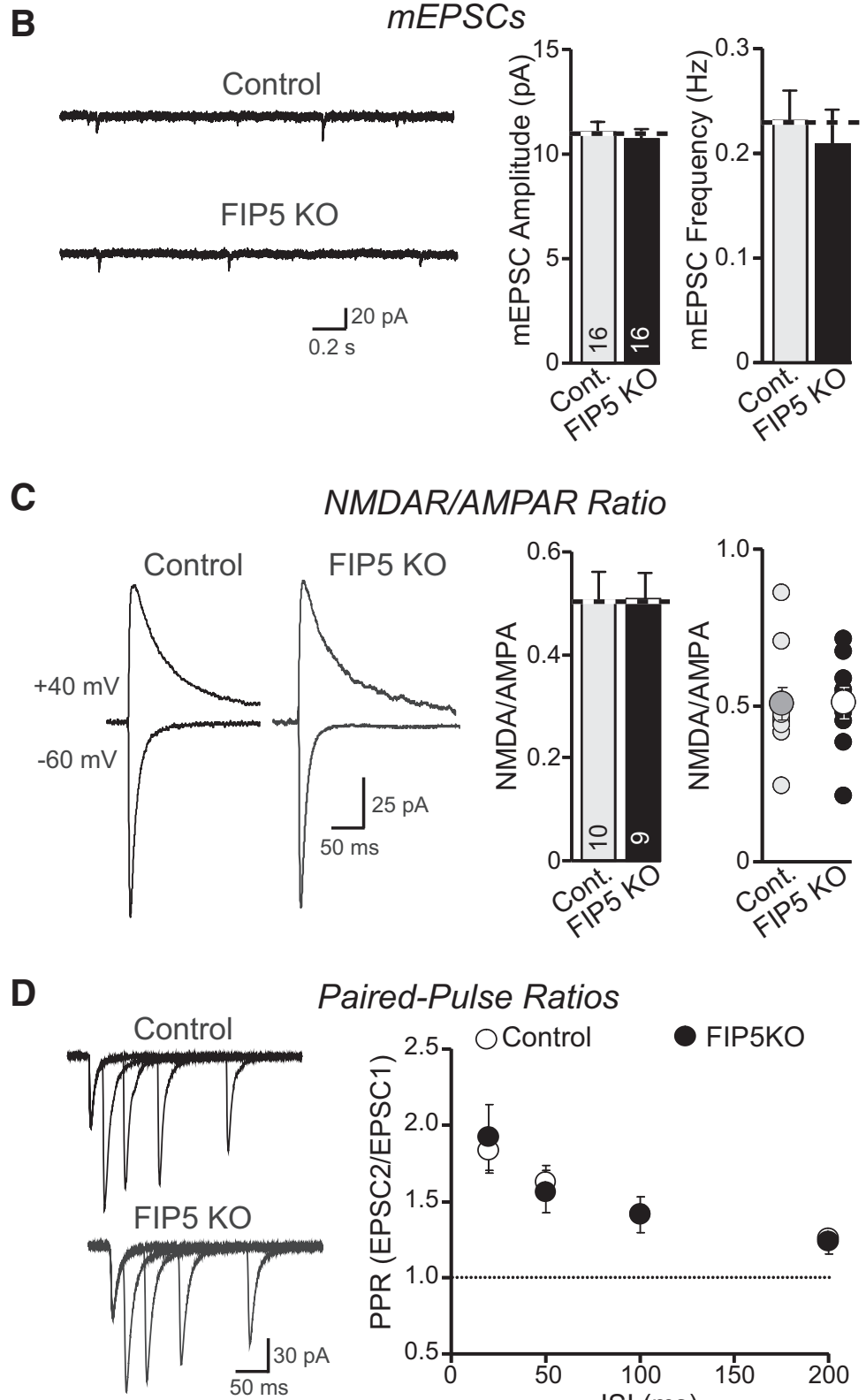

Paired-Pulse Ratios

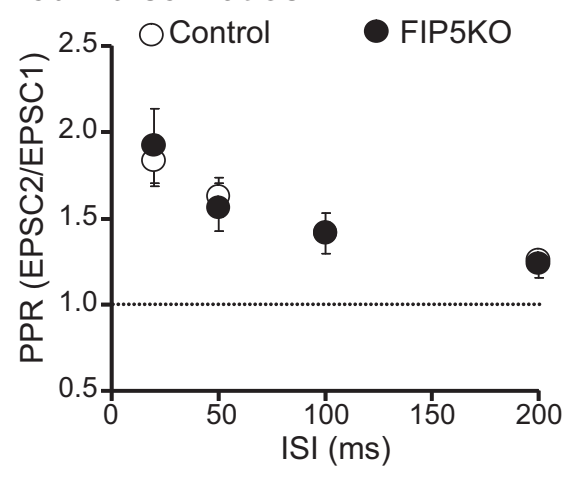

Figure 8. Rab11Fip5 is not required for basal transmission. $\boldsymbol{A}$, Sample traces (left) and summary graph of the linear fit slopes (right) (control, $7.2 \pm 0.3, n=7 ; \mathrm{KO}, 6.6 \pm 0.3, n=7$ ) for input-output measurements obtained by extracellular field recordings in acute hippocampal slices from heterozygous (control) and Rab11Fip5 K0 mice. $\boldsymbol{B}$, Sample traces (left) and mean amplitude (right) (control, $11.0 \pm 0.5 \mathrm{pA}, n=16 ; \mathrm{KO}, 10.7 \pm 0.5 \mathrm{pA}, n=16$ ) and frequency (control, $0.23 \pm 0.03 \mathrm{~Hz} ; \mathrm{KO}, 0.20 \pm$ $0.02 \mathrm{~Hz}$ ) of mEPSCs, which are unchanged in Rab11Fip5 K0 mice. C, The ratio of NMDAR- to AMPAR-mediated EPSCs is unchanged that, in the absence of an efficient transfer from early to recycling endosomes, most of the receptors shuttle back to the cell surface through a fast pathway as has been shown for transferrin receptors (Schonteich et al., 2008). Our findings support such a view because GluA1 receptors appear to be internalized normally initially ( 5 min after induction) but most likely are shuttled back to the membrane as no internalization is visible at $15 \mathrm{~min}$ after induction (Fig. 9). Alternatively, Rab11Fip5 might be involved in the trafficking of AMPARs to the late endosomes and lysosomes, a step that is important for LTD and ligand-induced trafficking of AMPARs (Ehlers, 2000; FernándezMonreal et al., 2012).

How does LTD relate to behavior? Strikingly, we found that Rab11Fip5 KO animals, which in our experiments show a complete lack of hippocampal LTD, performed as well as control animals in most behavioral tasks. One interpretation of this observation is that Rab11Fip5 is only strictly required for LTD within CA1 neurons, whereas other circuits retain normal LTD. Alternatively, LTD might not be required for most behaviors, except more cognitively challenging tasks, consistent with our observation that Rab11Fip5 $\mathrm{KO}$ animals display altered contextual fear extinction. Furthermore, in mutant animals lacking LTD, alternate forms of plasticity might compensate for this deficiency. In humans, autism spectrum disorder patients have been described with either total loss of Rab11Fip5 due to a chromosomal translocation (Roohi et al., 2008) or a Rab11Fip5 missense mutation in its Rab11 binding domain (Matsunami et al., 2014). Although it is tempting to hypothesize a link between the LTD phenotype observed in $\mathrm{KO}$ mice and autism spectrum disorders in humans, a fuller characterization of the Rab11Fip5 KO phenotype in different brain circuits is required to warrant such postulations.

$\leftarrow$

in Rab11Fip5 K0 mice. Representative EPSCs recorded at -60 $\mathrm{mV}$ and $40 \mathrm{mV}$ are shown with scatter plots of individual recordings. The different colored point indicates mean \pm SEM (Control, $0.50 \pm 0.05, n=10 ; \mathrm{KO}, 0.51 \pm 0.05, n=9$ ). $\boldsymbol{D}$, Paired-pulse ratios of AMPAR EPSCS are unchanged in Rab11Fip5 K0 mice. Representative EPSCs are shown on the left (PP20: control, $1.8 \pm 0.1 ; \mathrm{KO}, 1.9 \pm 0.2$; PP50: control, $1.6 \pm 0.1 ; \mathrm{KO}, 1.6 \pm 0.1 ; \mathrm{PP} 100$ : control, $1.42 \pm 0.06 ; \mathrm{KO}$, $1.4 \pm 0.1 ; \mathrm{PP} 200$ : control, $1.25 \pm 0.03 ; \mathrm{KO}, 1.24 \pm 0.08$; control, $n=10$; Rab11Fip5 KO $n=9$ ). Individual points represent mean \pm SEM. The number of cells recorded $(B, C)$ is indicated in each graph. Data are mean \pm SEM. No significant statistical differences were found using Student's $t$ test. 
A

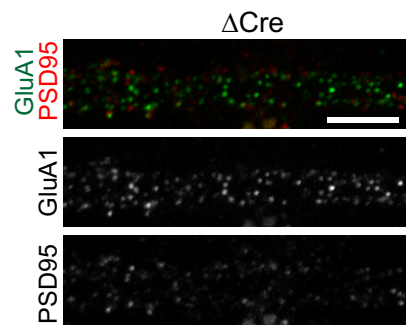

B

\begin{tabular}{|c|c|c|c|c|}
\hline GluA1 $\mathrm{Ab}$ & Wash & Chase & Fix \& Stain \\
\hline $15^{\prime}$ & $5^{\prime}$ & $3^{\prime}$ & $15^{\prime}$ or 5' \\
\hline
\end{tabular}

C
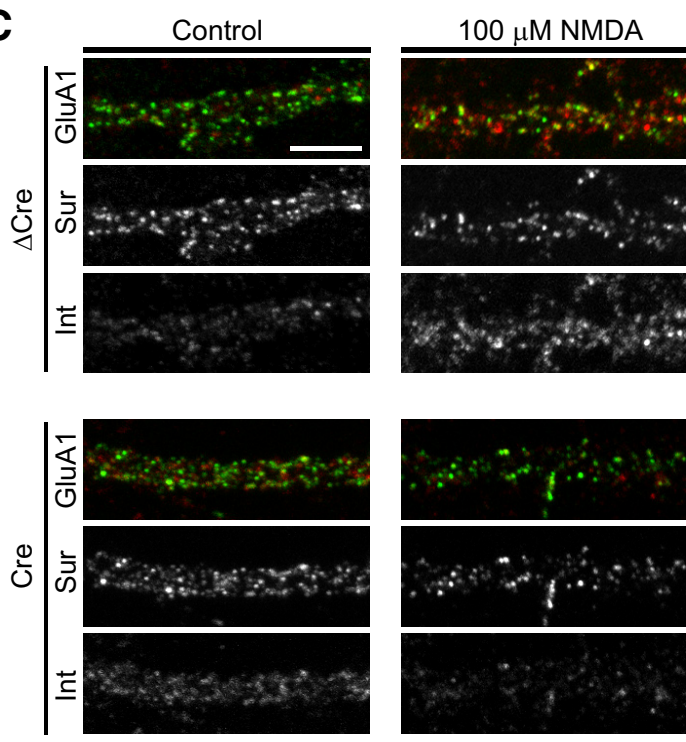

D
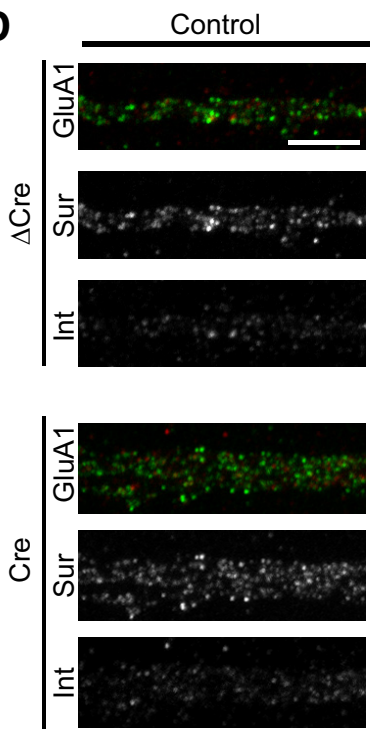

Synapse number quantification

ChemLTD protocol

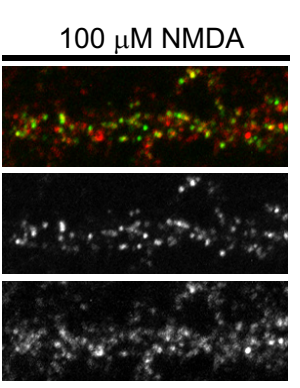

Internalization at $15 \mathrm{~min}$

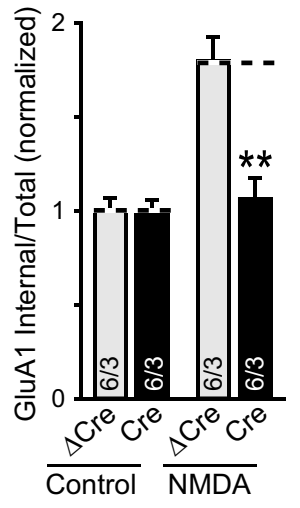

Internalization at $5 \mathrm{~min}$

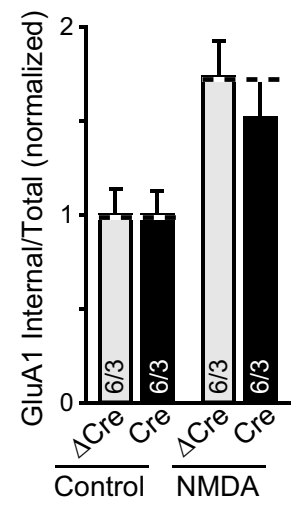

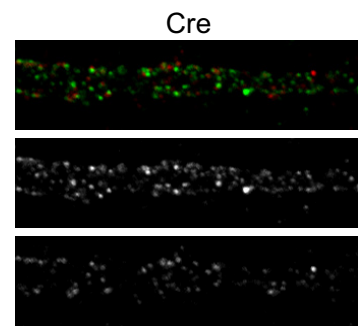
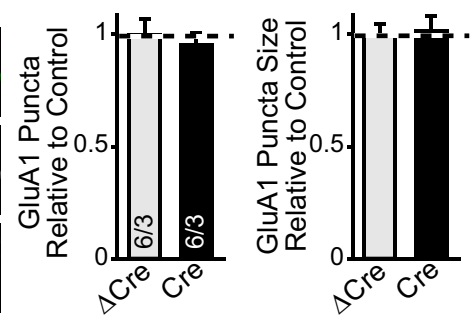

Figure 9. Rab11Fip5 is required for NMDA-triggered chemical LTD in neuronal cultures. $\boldsymbol{A}$, Synapse number and size are not altered by Rab11Fip5 K0 as determined by immunohistochemistry against GluA1. Representative images are shown on the left. Number of GluA1 puncta (center) and the size of these puncta (right) were not different in the two conditions. Both measurements are normalized to the control $\Delta$ Cre condition. Data are from four cultures and at least 6 random fields of view for each culture. $B$, Schematic of the NMDA-dependent GluA1 endocytosis protocol. To prevent cell toxicity, neurons are incubated in TTX, LY341495, and DNQX. After fixing, external GluA1 primary antibodies are labeled with secondary antibodies, followed by permeabilization and labeling of the internalized pool of GluA1 antibodies with another secondary antibody. C, NMDA-induced GluA1 internalization is blocked in the absence of Rab11Fip5. Representative images (left) and quantification (right) of the internalized GluA1 receptors. The level of internalization is normalized to that observed in the absence of NMDA application. A 15 min chase was performed. $D$, Initial internalization of GluA1 receptors appears unaffected in absence of Rab11Fip5. Same as in C, but a 5 min chase was performed. Data are from three independent cultures, and the number of random fields of view analyzed is indicated. ** $p<0.01$ (Student's $t$ test). 
In conclusion, this work identifies a novel role for Rab11Fip5 in LTD and suggests that Rab11 might be a key regulator of the receptor trafficking decisions that underlie synaptic plasticity. Further, the Rab11Fip5 KO mice can serve as a tool for assaying the role of LTD in generating or modifying behavior.

\section{References}

Ahmad M, Polepalli JS, Goswami D, Yang X, Kaeser-Woo YJ, Südhof TC, Malenka RC (2012) Postsynaptic complexin controls AMPA receptor exocytosis during LTP. Neuron 73:260-267. CrossRef Medline

Bacaj T, Wu D, Yang X, Morishita W, Zhou P, Xu W, Malenka RC, Südhof TC (2013) Synaptotagmin-1 and synaptotagmin-7 trigger synchronous and asynchronous phases of neurotransmitter release. Neuron 80:947-959. CrossRef Medline

Baetz NW, Goldenring JR (2013) Rab11-family interacting proteins define spatially and temporally distinct regions within the dynamic Rablladependent recycling system. Mol Biol Cell 24:643-658. CrossRef Medline

Beattie EC, Carroll RC, Yu X, Morishita W, Yasuda H, von Zastrow M, Malenka RC (2000) Regulation of AMPA receptor endocytosis by a signaling mechanism shared with LTD. Nat Neurosci 3:1291-1300. CrossRef Medline

Bhattacharyya S, Biou V, Xu W, Schlüter O, Malenka RC (2009) A critical role for PSD-95/AKAP interactions in endocytosis of synaptic AMPA receptors. Nat Neurosci 12:172-181. CrossRef Medline

Brown TC, Tran IC, Backos DS, Esteban JA (2005) NMDA receptordependent activation of the small GTPase Rab5 drives the removal of synaptic AMPA receptors during hippocampal LTD. Neuron 45:81-94. CrossRef Medline

Brown TC, Correia SS, Petrok CN, Esteban JA (2007) Functional compartmentalization of endosomal trafficking for the synaptic delivery of AMPA receptors during long-term potentiation. J Neurosci 27:13311-13315. CrossRef Medline

Bucci C, Parton RG, Mather IH, Stunnenberg H, Simons K, Hoflack B, Zerial M (1992) The small GTPase rab5 functions as a regulatory factor in the early endocytic pathway. Cell 70:715-728. CrossRef Medline

Carroll RC, Beattie EC, Xia H, Lüscher C, Altschuler Y, Nicoll RA, Malenka RC, von Zastrow M (1999) Dynamin-dependent endocytosis of ionotropic glutamate receptors. Proc Natl Acad Sci U S A 96:14112-14117. CrossRef Medline

Citri A, Bhattacharyya S, Ma C, Morishita W, Fang S, Rizo J, Malenka RC (2010) Calcium binding to PICK1 is essential for the intracellular retention of AMPA receptors underlying long-term depression. J Neurosci 30:16437-16452. CrossRef Medline

Corcoran KA, Desmond TJ, Frey KA, Maren S (2005) Hippocampal inactivation disrupts the acquisition and contextual encoding of fear extinction. J Neurosci 25:8978-8987. CrossRef Medline

Ehlers MD (2000) Reinsertion or degradation of AMPA receptors determined by activity-dependent endocytic sorting. Neuron 28:511-525. CrossRef Medline

Fernández-Monreal M, Brown TC, Royo M, Esteban JA (2012) The balance between receptor recycling and trafficking toward lysosomes determines synaptic strength during long-term depression. J Neurosci 32:1320013205. CrossRef Medline

Fielding AB, Schonteich E, Matheson J, Wilson G, Yu X, Hickson GR, Srivastava S, Baldwin SA, Prekeris R, Gould GW (2005) Rab11-FIP3 and FIP4 interact with Arf6 and the exocyst to control membrane traffic in cytokinesis. EMBO J 24:3389-3399. CrossRef Medline

Gerges NZ, Backos DS, Esteban JA (2004) Local control of AMPA receptor trafficking at the postsynaptic terminal by a small GTPase of the Rab family. J Biol Chem 279:43870-43878. CrossRef Medline

Hales CM, Griner R, Hobdy-Henderson KC, Dorn MC, Hardy D, Kumar R, Navarre J, Chan EK, Lapierre LA, Goldenring JR (2001) Identification and characterization of a family of Rab11-interacting proteins. J Biol Chem 276:39067-39075. CrossRef Medline

Hales CM, Vaerman JP, Goldenring JR (2002) Rab11 family interacting protein 2 associates with Myosin $\mathrm{Vb}$ and regulates plasma membrane recycling. J Biol Chem 277:50415-50421. CrossRef Medline

Ho A, Morishita W, Atasoy D, Liu X, Tabuchi K, Hammer RE, Malenka RC, Südhof TC (2006) Genetic analysis of Mint/X11 proteins: essential presynaptic functions of a neuronal adaptor protein family. J Neurosci 26: 13089-13101. CrossRef Medline
Holland PC, Bouton ME (1999) Hippocampus and context in classical conditioning. Curr Opin Neurobiol 9:195-202. CrossRef Medline

Horgan CP, McCaffrey MW (2009) The dynamic Rab11-FIPs. Biochem Soc Trans 37:1032-1036. CrossRef Medline

Huganir RL, Nicoll RA (2013) AMPARs and synaptic plasticity: the last 25 years. Neuron 80:704-717. CrossRef Medline

Jurado S, Biou V, Malenka RC (2010) A calcineurin/AKAP complex is required for NMDA receptor-dependent long-term depression. Nat Neurosci 13:1053-1055. CrossRef Medline

Jurado S, Goswami D, Zhang Y, Molina AJ, Südhof TC, Malenka RC (2013) LTP requires a unique postsynaptic SNARE fusion machinery. Neuron 77:542-558. CrossRef Medline

Kaeser PS, Deng L, Wang Y, Dulubova I, Liu X, Rizo J, Südhof TC (2011) RIM proteins tether $\mathrm{Ca}^{2+}$ channels to presynaptic active zones via a direct PDZ-domain interaction. Cell 144:282-295. CrossRef Medline

Kauer JA, Malenka RC (2007) Synaptic plasticity and addiction. Nat Rev Neurosci 8:844-858. CrossRef Medline

Khvotchev MV, Ren M, Takamori S, Jahn R, Südhof TC (2003) Divergent functions of neuronal Rab11b in $\mathrm{Ca}^{2+}$-regulated versus constitutive exocytosis. J Neurosci 23:10531-10539. Medline

Lee SH, Simonetta A, Sheng M (2004) Subunit rules governing the sorting of internalized AMPA receptors in hippocampal neurons. Neuron 43: 221-236. CrossRef Medline

Lindsay AJ, McCaffrey MW (2002) Rab11-FIP2 functions in transferrin recycling and associates with endosomal membranes via its $\mathrm{COOH}-$ terminal domain. J Biol Chem 277:27193-27199. CrossRef Medline

Lissin DV, Carroll RC, Nicoll RA, Malenka RC, von Zastrow M (1999) Rapid, activation-induced redistribution of ionotropic glutamate receptors in cultured hippocampal neurons. J Neurosci 19:1263-1272. Medline

Malenka RC, Bear MF (2004) LTP and LTD: an embarrassment of riches. Neuron 44:5-21. CrossRef Medline

Malinow R, Malenka RC (2002) AMPA receptor trafficking and synaptic plasticity. Annu Rev Neurosci 25:103-126. CrossRef Medline

Mao L, Takamiya K, Thomas G, Lin DT, Huganir RL (2010) GRIP1 and 2 regulate activity-dependent AMPA receptor recycling via exocyst complex interactions. Proc Natl Acad Sci U S A 107:19038-19043. CrossRef Medline

Matsunami N, Hensel CH, Baird L, Stevens J, Otterud B, Leppert T, Varvil T, Hadley D, Glessner JT, Pellegrino R, Kim C, Thomas K, Wang F, Otieno FG, Ho K, Christensen GB, Li D, Prekeris R, Lambert CG, Hakonarson H, et al. (2014) Identification of rare DNA sequence variants in high-risk autism families and their prevalence in a large case/control population. Mol Autism 5:5. CrossRef Medline

Maximov A, Pang ZP, Tervo DG, Südhof TC (2007) Monitoring synaptic transmission in primary neuronal cultures using local extracellular stimulation. J Neurosci Methods 161:75-87. CrossRef Medline

Oehlke O, Martin HW, Osterberg N, Roussa E (2011) Rab11b and its effector Rip11 regulate the acidosis-induced traffic of V-ATPase in salivary ducts. J Cell Physiol 226:638-651. CrossRef Medline

Pang ZP, Cao P, Xu W, Südhof TC (2010) Calmodulin controls synaptic strength via presynaptic activation of calmodulin kinase II. J Neurosci 30:4132-4142. CrossRef Medline

Pang ZP, Bacaj T, Yang X, Zhou P, Xu W, Südhof TC (2011) Doc2 supports spontaneous synaptic transmission by a $\mathrm{Ca}(2+)$-independent mechanism. Neuron 70:244-251. CrossRef Medline

Park M, Penick EC, Edwards JG, Kauer JA, Ehlers MD (2004) Recycling endosomes supply AMPA receptors for LTP. Science 305:1972-1975. CrossRef Medline

Pfeffer SR (2013) Rab GTPase regulation of membrane identity. Curr Opin Cell Biol 25:414-419. CrossRef Medline

Prekeris R, Klumperman J, Scheller RH (2000) A Rab11/Rip11 protein complex regulates apical membrane trafficking via recycling endosomes. Mol Cell 6:1437-1448. CrossRef Medline

Press B, Feng Y, Hoflack B, Wandinger-Ness A (1998) Mutant Rab7 causes the accumulation of cathepsin $\mathrm{D}$ and cation-independent mannose 6-phosphate receptor in an early endocytic compartment. J Cell Biol 140: 1075-1089. CrossRef Medline

Quirk GJ, Mueller D (2008) Neural mechanisms of extinction learning and retrieval. Neuropsychopharmacology 33:56-72. CrossRef Medline

Rao-Ruiz P, Rotaru DC, van der Loo RJ, Mansvelder HD, Stiedl O, Smit AB, Spijker S (2011) Retrieval-specific endocytosis of GluA2-AMPARs un- 
derlies adaptive reconsolidation of contextual fear. Nat Neurosci 14: 1302-1308. CrossRef Medline

Roohi J, Tegay DH, Pomeroy JC, Burkett S, Stone G, Stanyon R, Hatchwell E (2008) A de novo apparently balanced translocation [46,XY,t(2;9)(p13; p24)] interrupting RAB11FIP5 identifies a potential candidate gene for autism spectrum disorder Am J Med Genet B Neuropsychiatr Genet 147B: 411-417. CrossRef Medline

Rosenmund C, Stevens CF (1996) Definition of the readily releasable pool of vesicles at hippocampal synapses. Neuron 16:1197-1207. CrossRef Medline

Schlüter OM, Schmitz F, Jahn R, Rosenmund C, Südhof TC (2004) A complete genetic analysis of neuronal Rab3 function. J Neurosci 24:66296637. CrossRef Medline

Schonteich E, Wilson GM, Burden J, Hopkins CR, Anderson K, Goldenring JR, Prekeris R (2008) The Rip11/Rab11-FIP5 and kinesin II complex regulates endocytic protein recycling. J Cell Sci 121:3824-3833. CrossRef Medline

Sheff DR, Daro EA, Hull M, Mellman I (1999) The receptor recycling pathway contains two distinct populations of early endosomes with different sorting functions. J Cell Biol 145:123-139. CrossRef Medline

Sheng M, Lee SH (2001) AMPA receptor trafficking and the control of synaptic transmission. Cell 105:825-828. CrossRef Medline

Simon GC, Prekeris R (2008) Mechanisms regulating targeting of recycling endosomes to the cleavage furrow during cytokinesis. Biochem Soc Trans 36:391-394. CrossRef Medline

Stenmark H (2009) Rab GTPases as coordinators of vesicle traffic. Nat Rev Mol Cell Biol 10:513-525. CrossRef Medline
Südhof TC (2012) The presynaptic active zone. Neuron 75:11-25. CrossRef Medline

Sugawara K, Shibasaki T, Mizoguchi A, Saito T, Seino S (2009) Rab11 and its effector Rip11 participate in regulation of insulin granule exocytosis. Genes Cells 14:445-456. CrossRef Medline

van der Sluijs P, Hull M, Webster P, Mâle P, Goud B, Mellman I (1992) The small GTP-binding protein rab4 controls an early sorting event on the endocytic pathway. Cell 70:729-740. CrossRef Medline

Wang Z, Edwards JG, Riley N, Provance DW Jr, Karcher R, Li XD, Davison IG, Ikebe M, Mercer JA, Kauer JA, Ehlers MD (2008) Myosin Vb mobilizes recycling endosomes and AMPA receptors for postsynaptic plasticity. Cell 135:535-548. CrossRef Medline

Welsh GI, Leney SE, Lloyd-Lewis B, Wherlock M, Lindsay AJ, McCaffrey MW, Tavaré JM (2007) Rip11 is a Rab11- and AS160-RabGAP-binding protein required for insulin-stimulated glucose uptake in adipocytes. J Cell Sci 120:4197-4208. CrossRef Medline

Wilcke M, Johannes L, Galli T, Mayau V, Goud B, Salamero J (2000) Rab11 regulates the compartmentalization of early endosomes required for efficient transport from early endosomes to the trans-Golgi network. J Cell Biol 151:1207-1220. CrossRef Medline

Wilson GM, Fielding AB, Simon GC, Yu X, Andrews PD, Hames RS, Frey AM, Peden AA, Gould GW, Prekeris R (2005) The FIP3-Rab11 protein complex regulates recycling endosome targeting to the cleavage furrow during late cytokinesis. Mol Biol Cell 16:849-860. CrossRef Medline

Xu W, Schlüter OM, Steiner P, Czervionke BL, Sabatini B, Malenka RC (2008) Molecular dissociation of the role of PSD-95 in regulating synaptic strength and LTD. Neuron 57:248-262. CrossRef Medline 